\title{
Molecular Data Reveals Rich Diversity of the Sequestrate Genus Melanogaster (Boletales, Paxillaceae) with Emphasis on the Species from China
}

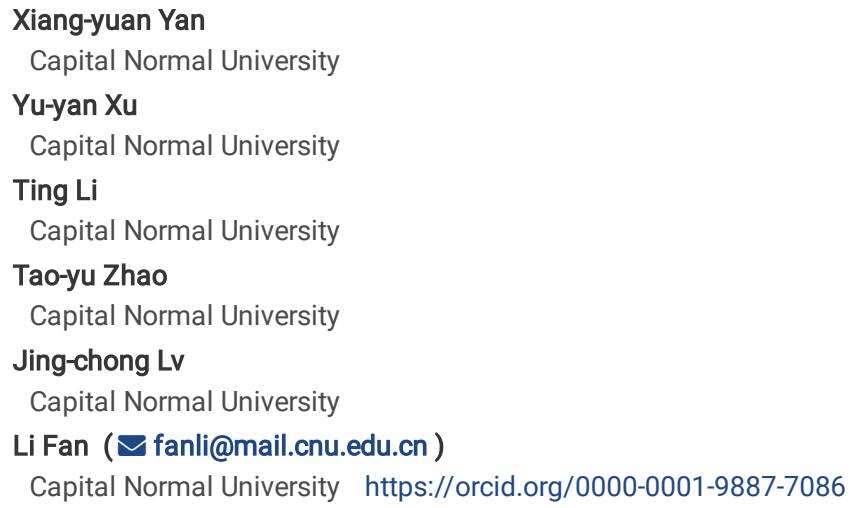

Research

Keywords: false truffle, hypogeous fungi, new taxa, phylogeny, taxonomy

Posted Date: November 4th, 2020

DOI: https://doi.org/10.21203/rs.3.rs-100635/v1

License: (c) (1) This work is licensed under a Creative Commons Attribution 4.0 International License. Read Full License 


\section{Abstract}

Malanogaster are ectomycorrhizal fungi characterized by hypogeous fruitbodies. Many ITS rDNA sequences of Malanogaster are recovered from molecular surveys of fungal communities, and remain insufficiently identified making it difficult to determine whether these sequences represent conspecific or novel taxa. In this study, the ITS sequences of Malanogaster were collected comprehensively and analyzed within ITS-based phylogenetic framework. Twenty-one distinct phylogenetic species can be distinguished based on the ITS phylogeny and a threshold of $98 \%$ ITS sequence identity, and most species of Melanogaster showed more than $98.1 \%$ intraspecific ITS identity and less than $97.9 \%$ interspecific identity. Ten species were recognized from China, but combined morphology, nine of which were described and illustrated in this manuscript, including 4 new species (M. minobovatus nov. sp., M. panzhihuaensis nov. sp., M. quercus nov. sp. and $M$. tomentellus nov. sp.), 1 new combination (M. obvatus comb. \& stat. nov.), and 4 known species ( $M$. broomeanus, $M$. shanxiensis, M. spinisporus, $M$. subglobisporus). Significantly amendments were added to $M$. spinisporus and $M$. subglobisporus. M. fusisporus was added a new mature specimen from type location, and the description and exquisite illustrations were provided also. The diagnostic characteristics of the genus Melanogaster and a key to the Chinese species of the genus Melanogaster were provided. A 28 Sphylogeny was also conducted to confirm the phylogenetic locations of Chinese Melanogaster species and "Alpova trappel", consistented with ITS analysis.

\section{Introduction}

The genus Melanogaster Corda. was erected by Corda (1831), belonging to Basidiomycota, Basidiomycetes, Boletales, Paxillaceae (Binder and Hibbett, 2006; Lacheva 2015). The species of this genus have partly or entirely hypogeous fruit bodies, commonly called false truffles, and found on almost all continents (Türkoğlu and Castellano, 2013). Their fruit bodies are tuber-like after dried especially, comprised of a central spore producing region (gleba) consisting of many global chambers surrounded by an outer skin (peridium), and spores are usually dark color. On ripening, their fruit bodies are gelatinous and elastic, the contents of the glebal chambers disintegrate and liquefy to produce a very dark and slimy spore mass, which is quite different with true truffle (Ainsworth 2005).

In China, the first two records are M. variegates (Vittad.) Tul. \& C. Tul. from Yunnan Province (Keissler and Lohwag 1937) and M. ambiguus (Vittad.) Tul. \& C. Tul. from Beijing (Teng 1963) ,but Wang et al. (1995) proposed them as new species M. ovoidisporus var. ovoidisporus Wang and M. spinisporus Wang, respectively. And, at the same time, Wang et al. (1995) described the other five species and varieties from China, including M. fusisporus var. fusisporus Y. Wang, M. fusisporus Wang var. obovatus K. Tao, Ming C. Chang \& B. Liu, M. natsii Wang, K. Tao et Liu, M. ovoidisporus Wang var. angustatosporus K. Tao, Ming C. Chang \& B. Liu, and M. subglobosporus K. Tao, Ming C. Chang \& B. Liu. In addition, Liu et al. (1989) reported M. shanxiensis B. Liu, K. Tao \& Ming C. Chang and M. obovatisporus B. Liu, K. Tao \& Ming C. Chang from Shanxi Province. Yuan and Sun (1996) reported M. broomeianus Berk. from Sichuan Province. Up to 1996, a total of 8 species and 2 varieties of the genus Melanogaster have been found in China.

With the rapid development of molecular techniques, molecular methods have revolutionized the study of taxonomy and phylogeny of hypogeous fungi (e.g. Bonito et al. 2010; Orihara et al. 2012). However, only a few molecular analyses focused on the taxonomy of gastroid Paxillineae (Moreau et al. 2011, 2013). In this study, the internal transcribed spacer region of ribosomal DNA (ITS) and nuclear ribosomal large subunit (nrLSU) were used to identify and analyze the taxonomy and systematics of Melnaogaster, and our aims are: (1) to clarify the phylogenetic diversity of Melanogaster species based on ITS and nrLSU sequences newly obtained from Chinese specimens in this study as well as downloaded from published databases (Genbank,

https://www.ncbi.nlm.nih.gov/genbank/), and (2) to describe the Chinese species of Melnaogaster, including 4 new species and 1 new combination.

\section{Materials And Methods Material studied}

Fresh specimens were collected from Shanxi and Yunnan provinces in China. They were dried and deposited in BJTC (Herbarium Biology Department, Capital Normal University). Other specimens were studied from HMAS (Herbarium Mycologicum Academiae Sinicae, Institute of Microbiology, Chinese Academy of Sciences) and KUN (Herbarium, Kunming Institute of Botany, Chinese Academy of Sciences). Macroscopic characters were recorded from fresh and dried specimens. Microscopic characters were examined from dried materials by mounting free-hand sections of basidiomata in $5 \% \mathrm{KOH}$, Melzer's reagent (Dring $1971)$, or $0.1 \%(w / v)$ cotton blue in lactic acid. Spore dimensions, excluding ornamentation, were based on 50 spores for each basidioma; measurements are presented as diameter (mean diam $\pm S D, n=50$ ) for each species. For scanning electron microscopy (SEM), ascospores were scraped from the dried gleba, placed onto double-sided tape that was mounted directly on the SEM stub, coated with a platinum-palladium film $8 \mathrm{~nm}$ thick using an ion-sputter coater (HITACHI E-1010), and examined with a HITACHI S-4800 SEM.

\section{Molecular methods}

Dried basidiomata were crushed by shaking for $45 \mathrm{~s}$ at $30 \mathrm{~Hz}$ 2-4 times (Mixer Mill MM301, Retsch, Haan, Germany) in a $1.5 \mathrm{ml}$ tube together with one $3 \mathrm{~mm}$ diam tungsten carbide ball. Total genomic DNA was extracted using the modified CTAB method (Gardes and Bruns 1993). A total of two nuclear loci were sequenced for this study, including ITS and nrLSU. The ITS region was amplified using the primers for ITS1f/ITS1/ITS4/ITS4B (White et al. 1990; Gardes and Bruns 1993). The primer pair LROR/LR5 (Vilgalys and Hester 1990) was used to amplify the nrLSU fragments. Polymerase chain reactions (PCRs) were performed in $25 \mu \mathrm{l}$ reactions containing DNA template $4 \mu \mathrm{l}$, primer $(10 \mu \mathrm{M} / \mathrm{L}) 2 \mu \mathrm{l}$ each, $2 \times$ Master Mix (Tiangen Biotech (Beijing) Co. Ltd.) $25 \mu$ l. PCR reactions were implemented as follows: an initial denaturation at $94^{\circ} \mathrm{C}$ for $3 \mathrm{~min}$; followed by 35 cycles at $94^{\circ} \mathrm{C}$ for $45 \mathrm{~s}, 55^{\circ} \mathrm{C}$ for $45 \mathrm{~s}, 72{ }^{\circ} \mathrm{C}$ for $1 \mathrm{~min}$; and a final extension at $72{ }^{\circ} \mathrm{C}$ for $10 \mathrm{~min}$. The PCR products were purified with a Gel Extraction \& PCR Purification Combo Kit (Spin-column) (Bioteke, Beijing, China) and then sequenced by Beijing Zhongkexilin Biotechnology Co. Ltd. (Beijing, China) used the same primers as in the PCR amplication. The products that failed to 
be sequenced were cloned into a pLB vector (Tiangen, Beijing) and then sequenced with primers: 23-mer (5' -CGACTCACTATAGGGAGAGCGGC-3') and M13R (5' -AAGAACATCGATTTTCCATGGCAG-3').

\section{Sequence preparation}

Total 22 ITS and 14 nrLSU fragments newly generated sequences were assembled and edited using SeqMan (DNA STAR package; DNAStar Inc., Madison, WI, USA) with generic-level identities for sequences confirmed via Blast queries of GenBank. Additional ITS and nrLSU sequences of Melanogaster and Alpova species were downloaded from GenBank, combined with our sequence database to create ITS and nrLSU phylogeny to illustrate the phylogenetic diversity in Melanogaster. The genus search tool in emerencia (http://www.emerencia.org/) was used to retrieve insufficiently identified ITS sequences from GenBank, whose pairwise similarity was most similar to identified Melanogaster species (Nilsson et al. 2005; Ryberg et al. 2009). The data set of compiled ITS and nrLSU sequences were filtered by removing sequences of poor quality or short length as well as sequences not belonging to Melanogaster based on BLAST (Altschul et al. 1997). Details of the taxa, specimens, host, origin and GenBank sequence accessions of ITS and 28S sequences employed in the phylogeny analyses were provided in Table 1 and Table 2 Respectively. 
Table 1

Sources of specimens and GenBank accession numbers for sequences used in this study. Sequences newly generated for this study are in bold.

\begin{tabular}{|c|c|c|c|c|c|c|}
\hline Taxon name & Specimen_voucher & Host & Sporocarp/ECM & Origin & nrDNA-LSU & Study \\
\hline Alpova alpestris & PAM07082629 & $\begin{array}{l}\text { Alnus alnobetula } \\
\text { subsp. alnobetula }\end{array}$ & Fruitbody (holotype) & France & NR 132847 & $\begin{array}{l}\text { Rochet et al. } \\
2011\end{array}$ \\
\hline Alpova alpestris & PAM07082629 & $\begin{array}{l}\text { Alnus alnobetula } \\
\text { subsp. alnobetula }\end{array}$ & fruitbody & France & HQ714696 & $\begin{array}{l}\text { Moreau et al. } \\
2011\end{array}$ \\
\hline Alpova alpestris & EDB080829 & $\begin{array}{l}\text { Alnus alnobetula } \\
\text { subsp. alnobetula }\end{array}$ & fruitbody & France & HQ714775 & $\begin{array}{l}\text { Moreau et al. } \\
2011\end{array}$ \\
\hline Alpova alpestris & PAM09082201 & $\begin{array}{l}\text { Alnus alnobetula } \\
\text { subsp. alnobetula }\end{array}$ & fruitbody & France & HQ714777 & $\begin{array}{l}\text { Moreau et al. } \\
2011\end{array}$ \\
\hline Alpova alpestris & PAM07090501 & $\begin{array}{l}\text { Alnus alnobetula } \\
\text { subsp. suaveolens }\end{array}$ & fruitbody & France & HQ714691 & $\begin{array}{l}\text { Moreau et al. } \\
2011\end{array}$ \\
\hline Alpova alpestris & PAM07090501 & $\begin{array}{l}\text { Alnus alnobetula } \\
\text { subsp. suaveolens }\end{array}$ & fruitbody & France & HQ714692 & $\begin{array}{l}\text { Moreau et al. } \\
2011\end{array}$ \\
\hline Alpova alpestris & PAM08090302 & $\begin{array}{l}\text { Alnus alnobetula } \\
\text { subsp. suaveolens }\end{array}$ & fruitbody & France & HQ714721 & $\begin{array}{l}\text { Moreau et al. } \\
2011\end{array}$ \\
\hline Alpova alpestris & PAM09082802 & $\begin{array}{l}\text { Alnus alnobetula } \\
\text { subsp. alnobetula }\end{array}$ & fruitbody & France & HQ714776 & $\begin{array}{l}\text { Moreau et al. } \\
2011\end{array}$ \\
\hline $\begin{array}{l}\text { Alpova } \\
\text { austroalnicola }\end{array}$ & LS Dominguez 2290 & Alnus acuminata & fruitbody & Argentina & HQ714793 & $\begin{array}{l}\text { Moreau et al. } \\
2011\end{array}$ \\
\hline $\begin{array}{l}\text { Alpova cf. } \\
\text { cinnamomeus }\end{array}$ & PAM09082702 & $\begin{array}{l}\text { Alnus alnobetula } \\
\text { subsp. alnobetula }\end{array}$ & fruitbody & France & HQ714779 & $\begin{array}{l}\text { Moreau et al. } \\
2011\end{array}$ \\
\hline $\begin{array}{l}\text { Alpova } \\
\text { cinnamomeus }\end{array}$ & Hayward Z5 & - & ECM & - & KF836000 & $\begin{array}{l}\text { Hayward \& } \\
\text { Horton } 2014\end{array}$ \\
\hline $\begin{array}{l}\text { Alpova } \\
\text { cinnamomeus }\end{array}$ & BROWN FP73 & - & ECM & - & KF835996 & $\begin{array}{l}\text { Hayward \& } \\
\text { Horton } 2014\end{array}$ \\
\hline $\begin{array}{l}\text { Alpova } \\
\text { cinnamomeus }\end{array}$ & $\begin{array}{l}\text { MQ18R050-HRL2671- } \\
\text { QFB30133 }\end{array}$ & - & fruitbody & Canada & MN992116 & Unpublished \\
\hline Alpova concolor & OSC:65696 & - & holotype & - & NR_154686 & $\begin{array}{l}\text { Hayward\&Horton } \\
2014\end{array}$ \\
\hline Alpova concolor & OSC:65696 & - & fruitbody & - & KF835994 & $\begin{array}{l}\text { Hayward \& } \\
\text { Horton } 2014\end{array}$ \\
\hline Alpova concolor & UBC F14673 & - & ECM & - & KF835997 & $\begin{array}{l}\text { Hayward \& } \\
\text { Horton } 2014\end{array}$ \\
\hline Alpova corsicus & PAM07090803 & $\begin{array}{l}\text { Alnus alnobetula } \\
\text { subsp. suaveolens }\end{array}$ & fruitbody & France & HQ714699 & $\begin{array}{l}\text { Moreau et al. } \\
2011\end{array}$ \\
\hline Alpova corsicus & FR2 & Alnus cordata & fruitbody & France & HQ714766 & $\begin{array}{l}\text { Moreau et al. } \\
2011\end{array}$ \\
\hline Alpova corsicus & PAM05102601 & Alnus cordata & fruitbody & France & HQ714698 & $\begin{array}{l}\text { Moreau et al. } \\
2011\end{array}$ \\
\hline $\begin{array}{l}\text { Alpova } \\
\text { diplophloeus }\end{array}$ & Hayward1 & - & ECM & - & KF835992 & $\begin{array}{l}\text { Hayward \& } \\
\text { Horton. } 2014\end{array}$ \\
\hline $\begin{array}{l}\text { Alpova } \\
\text { diplophloeus }\end{array}$ & Hayward 2 & - & ECM & - & KF836001 & $\begin{array}{l}\text { Hayward \& } \\
\text { Horton } 2014\end{array}$ \\
\hline $\begin{array}{l}\text { Alpova } \\
\text { diplophloeus }\end{array}$ & OSC59767:Trappe11088 & - & fruitbody & - & DQ989497 & Unpublished \\
\hline Alpova komoviana & LIP:PAM10081201 & - & fruitbody & - & JQ436850 & $\begin{array}{l}\text { Moreau et al. } \\
2013\end{array}$ \\
\hline Alpova sp. & OSC:59767 & - & fruitbody & - & KF835995 & $\begin{array}{l}\text { Hayward \& } \\
\text { Horton } 2014\end{array}$ \\
\hline Alpova sp. & - & - & ECM & Spain & AJ419181 & $\begin{array}{l}\text { Martin \& Raidl } \\
2002\end{array}$ \\
\hline Alpova sp. & TK1622 & - & fruitbody & USA & AY558739(its1) & Unpublished \\
\hline Alpova trappei & OSC JMT 16394 & - & fruitbody & USA & AF074920 & $\begin{array}{l}\text { Grubishaet al. } \\
2002\end{array}$ \\
\hline Alpova trappei & SNF105 & - & fruitbody & USA & AY558738(its1) & Unpublished \\
\hline Alpova trappei & OSC158328 JLF2124 & - & fruitbody & USA & MN984306 & Unpublished \\
\hline
\end{tabular}




\begin{tabular}{|c|c|c|c|c|c|c|}
\hline Taxon name & Specimen_voucher & Host & Sporocarp/ECM & Origin & nrDNA-LSU & Study \\
\hline Alpova trappei & OSC158329 JLF4410 & - & fruitbody & USA & MN984307 & Unpublished \\
\hline Gyrodon lividus & - & - & - & Germany & DQ534568 & $\begin{array}{l}\text { Binder \& Hibbett } \\
2006\end{array}$ \\
\hline M. ambiguus & B-2220 & - & fruitbody & Hungary & AJ555510 & Unpublished \\
\hline M. ambiguus & 51745 & - & fruitbody & Hungary & AJ555511 & Unpublished \\
\hline M. ambiguus & B-1599 & - & fruitbody & Hungary & AJ555512 & Unpublished \\
\hline M. ambiguus & B-2409 & - & fruitbody & Hungary & AJ555514 & Unpublished \\
\hline M. ambiguus & Ch12 & Corylus avellana & ECM & Poland & KX438335 & Unpublished \\
\hline M. broomeanus & BJTC FAN909 & Lespedeza bicolor & fruitbody & China & $\sqrt{ }$ & In this study \\
\hline M. broomeanus & BJTC FAN1230-A & Pinus bungeana & fruitbody & China & $\sqrt{ }$ & In this study \\
\hline M. broomeanus & BJTC FAN1230-B & Pinus bungeana & fruitbody & China & $\sqrt{ }$ & In this study \\
\hline M. broomeianus & 48353 & - & fruitbody & Hungary & AJ555516 & Unpublished \\
\hline M. broomeianus & B-1616 & - & fruitbody & Hungary & AJ555517 & Unpublished \\
\hline M. broomeianus & RBG Kew K(M)124251 & - & fruitbody & UK & EU784370 & Brock et al. 2009 \\
\hline M. broomeianus & B-2331 & - & fruitbody & Hungary & AJ555530 & Unpublished \\
\hline M. broomeianus & 23633 & - & fruitbody & Hungary & AJ555518 & Unpublished \\
\hline M. cf. intermedius & RBG Kew K(M)122480 & - & fruitbody & UK & EU784371 & Brock et al. 2009 \\
\hline M. euryspermus & - & - & fruitbody & USA: & AY918954 & Frank et al. 2006 \\
\hline M. intermedius & B-1770 & - & fruitbody & Hungary & AJ555515 & Unpublished \\
\hline M. intermedius & RBG Kew K(M)130202 & - & fruitbody & UK & EU784372 & Brock et al. 2009 \\
\hline M. intermedius & MT48 & Fagus sylvatica & ECM & Germany & KX168661 & Unpublished \\
\hline M. luteus & PAM09082801 & $\begin{array}{l}\text { Alnus incana subsp. } \\
\text { incana }\end{array}$ & fruitbody & France & HQ714780 & $\begin{array}{l}\text { Moreau et al. } \\
2011\end{array}$ \\
\hline M. luteus & Mon06 & $\begin{array}{l}\text { Alnus incana subsp. } \\
\text { incana }\end{array}$ & fruitbody & Montene & HQ714794 & $\begin{array}{l}\text { Moreau et al. } \\
2011\end{array}$ \\
\hline M. macrosporus & $\mathrm{Cl}-94$ & - & fruitbody & Hungary & AJ555526 & Unpublished \\
\hline M. macrosporus & B-2254 & - & fruitbody & Hungary & AJ555528 & Unpublished \\
\hline M. minobovatus & BJTC FAN911 & Pinus bungeana & fruitbody(holotype) & China & Not submitted & In this study \\
\hline M. obovatus & BJTC FAN1102 & Quercus variabilis & fruitbody & China & Not submitted & In this study \\
\hline M. obovatus & BJTC FAN1091 & Quercus variabilis & fruitbody(epitype) & China & Not submitted & In this study \\
\hline M. obovatus & BJTC FAN1208 & Quercus sp. & fruitbody & China & Not submitted & In this study \\
\hline M. panzhihuaensis & HMAS81915 & Pinus yunnanensis & fruitbody(holotype) & China & Not submitted & In this study \\
\hline M. quercus & BJTC FAN808 & Quercus sp. & fruitbody & China & Not submitted & In this study \\
\hline M. quercus & BJTC FAN809 & Quercus sp. & fruitbody(holotype) & China & Not submitted & In this study \\
\hline M. rivularis & PAM08090514 & Alnus glutinosa & fruitbody & France & HQ714731 & $\begin{array}{l}\text { Moreau et al. } \\
2011\end{array}$ \\
\hline M. rivularis & PAM08090514 & Alnus glutinosa & fruitbody & France & HQ714767 & $\begin{array}{l}\text { Moreau et al. } \\
2011\end{array}$ \\
\hline M. rivularis & PAM08090514 & Alnus glutinosa & fruitbody & France & NR_132848 & $\begin{array}{l}\text { Moreau et al. } \\
2011\end{array}$ \\
\hline M. shanxiensis & HMAS81910 & Lespedeza bicolor & fruitbody(holotype) & China & Not submitted & In this study \\
\hline M. spinisporus & BJTC FAN1085 & Quercus variabilis & fruitbody & China & Not submitted & In this study \\
\hline M. spinisporus & BJTC FAN1092 & Quercus variabilis & fruitbody & China & Not submitted & In this study \\
\hline M. spinisporus & BJTC FAN936-A & Pinus bungeana & fruitbody & China & Not submitted & In this study \\
\hline M. spinisporus & BJTC FAN936-B & Pinus bungeana & fruitbody & China & Not submitted & In this study \\
\hline M. spinisporus & BJTC FAN936-C & Pinus bungeana & fruitbody & China & Not submitted & In this study \\
\hline
\end{tabular}




\begin{tabular}{|c|c|c|c|c|c|c|}
\hline Taxon name & Specimen_voucher & Host & Sporocarp/ECM & Origin & nrDNA-LSU & Study \\
\hline M. spinisporus & BJTC FAN938 & Pinus bungeana & fruitbody & China & Not submitted & In this study \\
\hline M. spinisporus & BJTC FAN941-A & Ulmus sp. & fruitbody(epitype) & China & Not submitted & In this study \\
\hline M. spinisporus & BJTC FAN941-B & Ulmus sp. & fruitbody & China & Not submitted & In this study \\
\hline M. subglobisporus & HMAS81919 & - & fruitbody(epitype) & China & Not submitted & In this study \\
\hline M. tomentellus & BJTC FAN539 & Pinus sp. & fruitbody(holotype) & China & Not submitted & In this study \\
\hline M. tuberiformis & B-1295 & - & fruitbody & Romania & AJ555527 & Unpublished \\
\hline M. variegatus & B-1438 & - & fruitbody & Hungary & AJ555523 & Unpublished \\
\hline M. variegatus & B-1348 & - & fruitbody & Hungary & AJ555534 & Unpublished \\
\hline M. vittadinii & 33090 & - & fruitbody & Hungary & AJ555525 & Unpublished \\
\hline M.ambiguus & HMAS68237 & - & fruitbody & UK & Not submitted & In this study \\
\hline Melanogaster sp. & Soc1324 & Quercus garryana & - & USA: & JN022499 & Unpublished \\
\hline Melanogastersp. & LM3494 & Quercus sp. & ECM & France & KM576463 & Suz et al. 2014 \\
\hline Melanogastersp. & OSC 59776 & - & fruitbody & USA & KT968555 & Unpublished \\
\hline Melanogaster sp. & OSC 59778 & - & fruitbody & USA & KT968556 & Unpublished \\
\hline Melanogaster sp. & Melanog002FRA & Alnus cordata & ECM & France & KU924526 & Unpublished \\
\hline Melanogaster sp. & Melanog004FRA & Alnus cordata & ECM & France & KU924527 & Unpublished \\
\hline Melanogastersp. & Melanog005FRA & Alnus cordata & ECM & France & KU924528 & Unpublished \\
\hline Melanogaster sp. & Melanog006FRA & Alnus cordata & ECM & France & KU924529 & Unpublished \\
\hline Melanogaster sp. & Melanog007FRA & Alnus cordata & ECM & France & KU924530 & Unpublished \\
\hline Melanogaster sp. & Melanog008FRA & Alnus cordata & ECM & France & KU924531 & Unpublished \\
\hline Melanogastersp. & Melanog011FRA & Alnus cordata & ECM & France & KU924533 & Unpublished \\
\hline Melanogaster sp. & Melanog012FRA & Alnus cordata & ECM & France & KU924534 & Unpublished \\
\hline Melanogaster sp. & Melanog018FRA & Alnus alnobetula & ECM & France & KU924535 & Unpublished \\
\hline Melanogaster sp. & Melanog019FRA & Alnus alnobetula & ECM & France & KU924536 & Unpublished \\
\hline Melanogastersp. & MT15 & Fagus sylvatica & ECM & Germany: & KX168646 & Unpublished \\
\hline Melanogastersp. & LMKR1187 & Pinus sylvestris & ECM & UK & MF352733 & Suz et al. 2017 \\
\hline Melanogastersp. & Soc1321 & Quercus garryana & fruitbody & USA: & JN022515 & Unpublished \\
\hline $\begin{array}{l}\text { Neoalpova } \\
\text { rubescens }\end{array}$ & 16942 & - & fruitbody & Italy & JF908774 & $\begin{array}{l}\text { Osmundson et } \\
\text { al. } 2013\end{array}$ \\
\hline $\begin{array}{l}\text { Neoalpova } \\
\text { rubescens }\end{array}$ & M. Zotti 2oct2008 & Fagus sylvatica & fruitbody & - & JQ436851 & $\begin{array}{l}\text { Moreau et al. } \\
2013\end{array}$ \\
\hline $\begin{array}{l}\text { Paragyrodon } \\
\text { sphaerosporus }\end{array}$ & MB06-066 & - & - & USA & GU187540 & $\begin{array}{l}\text { Binder et al. } \\
2010\end{array}$ \\
\hline Paxillus adelphus & TL:127-0003 & Alnus glutinosa & fruitbody & France & NR_158830 & $\begin{array}{l}\text { Jargeat et al. } \\
2016\end{array}$ \\
\hline $\begin{array}{l}\text { Paxillus } \\
\text { rubicundulus }\end{array}$ & K:M190474 & Alnus & fruitbody & UK & NR_147640 & $\begin{array}{l}\text { Jargeat et al. } \\
2016\end{array}$ \\
\hline uncultured Alpova & - & $\begin{array}{l}\text { Alnus alnobetula } \\
\text { subsp. crispa }\end{array}$ & ECM & Canada & MK285738 & Unpublished \\
\hline uncultured Alpova & - & $\begin{array}{l}\text { Alnus rhombifolia or } \\
\text { Betula occidentalis }\end{array}$ & ECM & USA & JX198512 & Bogar et al. 2013 \\
\hline $\begin{array}{l}\text { Uncultured } \\
\text { Boletaceae }\end{array}$ & clone B8 & $\begin{array}{l}\text { Lithocarpus } \\
\text { densiflorus }\end{array}$ & ECM & USA & DQ273364 & $\begin{array}{l}\text { Bergemann et al. } \\
2006\end{array}$ \\
\hline $\begin{array}{l}\text { Uncultured } \\
\text { Boletaceae }\end{array}$ & LP110023 & Quercus liaotungensis & ECM & CHINA & JQ318611 & Unpublished \\
\hline $\begin{array}{l}\text { Uncultured } \\
\text { Boletaceae }\end{array}$ & - & $\begin{array}{l}\text { Lithocarpus } \\
\text { densiflorus }\end{array}$ & ECM & USA: & DQ273366 & $\begin{array}{l}\text { Bergemann et al. } \\
2006\end{array}$ \\
\hline
\end{tabular}




\begin{tabular}{|c|c|c|c|c|c|c|}
\hline Taxon name & Specimen_voucher & Host & Sporocarp/ECM & Origin & nrDNA-LSU & Study \\
\hline $\begin{array}{l}\text { Uncultured } \\
\text { ectomycorrhiza } \\
\text { (Melanogastraceae) }\end{array}$ & E3 & - & soil & Denmark & AM159585 & $\begin{array}{l}\text { Kjoller et al. } \\
2006\end{array}$ \\
\hline $\begin{array}{l}\text { Uncultured } \\
\text { ectomycorrhizal } \\
\text { fungus }\end{array}$ & L7139a & alder species & ECM & Europe & JN197963 & Unpublished \\
\hline $\begin{array}{l}\text { Uncultured } \\
\text { ectomycorrhizal } \\
\text { fungus }\end{array}$ & S376 & alder species & ECM & - & JN198097 & Unpublished \\
\hline $\begin{array}{l}\text { Uncultured } \\
\text { ectomycorrhizal } \\
\text { fungus }\end{array}$ & S414 & alder species & ECM & Europe & JN198124 & Unpublished \\
\hline $\begin{array}{l}\text { Uncultured } \\
\text { ectomycorrhizal } \\
\text { fungus }\end{array}$ & ecm_Jo9V422 & Alnus sp. & ECM & France & JX989839 & Roy et al. 2013 \\
\hline $\begin{array}{l}\text { Uncultured } \\
\text { ectomycorrhizal } \\
\text { fungus }\end{array}$ & ecm_HL9I116 & Alnus sp. & ECM & France & JX989860 & Roy et al. 2013 \\
\hline $\begin{array}{l}\text { Uncultured } \\
\text { ectomycorrhizal } \\
\text { fungus }\end{array}$ & ecm_HL9I510 & Alnus sp. & ECM & France & JX989867 & Roy et al. 2013 \\
\hline $\begin{array}{l}\text { Uncultured } \\
\text { ectomycorrhizal } \\
\text { fungus }\end{array}$ & ecm_AZA815 & Alnus sp. & ECM & France & JX989932 & Roy et al. 2013 \\
\hline $\begin{array}{l}\text { Uncultured } \\
\text { ectomycorrhizal } \\
\text { fungus }\end{array}$ & ecm_FS511 & Alnus sp. & ECM & France & JX990028 & Roy et al. 2013 \\
\hline $\begin{array}{l}\text { Uncultured } \\
\text { ectomycorrhizal } \\
\text { fungus }\end{array}$ & ecm_Co8J3C306 & Alnus sp. & ECM & France & JX990041 & Roy et al. 2013 \\
\hline $\begin{array}{l}\text { Uncultured } \\
\text { ectomycorrhizal } \\
\text { fungus }\end{array}$ & ecm_AR91525 & Alnus sp. & ECM & France & JX990064 & Roy et al. 2013 \\
\hline Uncultured fungus & TKSCAT1649 & Glaucomys sabrinus & $\begin{array}{l}\text { environmental_sample: } \\
\text { small mammal scat }\end{array}$ & USA & $\begin{array}{l}\text { AY558728 } \\
\text { (its1) }\end{array}$ & Unpublished \\
\hline $\begin{array}{l}\text { Uncultured } \\
\text { Melanogaster }\end{array}$ & MFT57 & Fagus sy/vatica & ECM & Germany & FJ403505 & Pena et al. 2010 \\
\hline $\begin{array}{l}\text { Uncultured } \\
\text { Melanogaster }\end{array}$ & - & - & environmental_sample & Iran & FR852281 & $\begin{array}{l}\text { Bahram et al. } \\
2012\end{array}$ \\
\hline $\begin{array}{l}\text { Uncultured } \\
\text { Melanogaster }\end{array}$ & QL045 & Quercus liaotungensis & ECM & China & HM105535 & Wang et al. 2012 \\
\hline $\begin{array}{l}\text { Uncultured } \\
\text { Melanogaster }\end{array}$ & clone S9 & - & ECM & Germany & HQ336669 & Unpublished \\
\hline $\begin{array}{l}\text { Uncultured } \\
\text { Melanogaster }\end{array}$ & clone vial332 & Pseudotsuga menziesii & ECM & Canada & JN652972 & Unpublished \\
\hline $\begin{array}{l}\text { Uncultured } \\
\text { Melanogaster }\end{array}$ & ECM_alnus_Melalute & Alnus sp. & ECM & France & JQ890286 & Roy et al. 2013 \\
\hline $\begin{array}{l}\text { Uncultured } \\
\text { Melanogaster }\end{array}$ & ECM_alnus_Melarivu & Alnus sp. & ECM & France & JQ890287 & Roy et al. 2013 \\
\hline $\begin{array}{l}\text { Uncultured } \\
\text { Melanogaster }\end{array}$ & $\mathrm{Mv}$ & - & forest soil & Germany & JX030011 & Unpublished \\
\hline $\begin{array}{l}\text { Uncultured } \\
\text { Melanogaster }\end{array}$ & МTH36 & Fagus sy/vatica & ECM & Germany & KT020803 & Unpublished \\
\hline $\begin{array}{l}\text { Uncultured } \\
\text { Melanogaster }\end{array}$ & clone UVIC42 & Pseudotsuga menziesii & environmental_sample & Canada & KT272124 & $\begin{array}{l}\text { Kranabetter et al. } \\
2015\end{array}$ \\
\hline
\end{tabular}


Table 2

Sources of specimens and GenBank accession numbers for sequences used in this study. Sequences newly generated for this study are in bold.

\begin{tabular}{|c|c|c|c|c|c|c|}
\hline Taxon name & Specimen_voucher & Host & Sporocarp/ECM & Origin & $\begin{array}{l}\text { nrDNA- } \\
\text { LSU }\end{array}$ & Study \\
\hline Alpova. australis & CORD LSD 2291 & - & - & - & AY377575 & $\begin{array}{l}\text { Nouhra et } \\
\text { al. } 2005\end{array}$ \\
\hline Alpova australis & CORD LSD 2290 & - & - & - & AY377574 & $\begin{array}{l}\text { Nouhra et } \\
\text { al. } 2006\end{array}$ \\
\hline $\begin{array}{l}\text { Alpova } \\
\text { diplophloeus }\end{array}$ & OSC 34455 & - & fruitbody & - & AY377573 & $\begin{array}{l}\text { Nouhra et } \\
\text { al. } 2007\end{array}$ \\
\hline $\begin{array}{l}\text { Alpova } \\
\text { diplophloeus }\end{array}$ & - & - & - & - & AF352035 & $\begin{array}{l}\text { Jarosch \& } \\
\text { Besl } 2001\end{array}$ \\
\hline $\begin{array}{l}\text { Alpova } \\
\text { diplophloeus }\end{array}$ & OSC JMT 17685 & - & fruitbody & - & AF071454 & $\begin{array}{l}\text { Grubisha et } \\
\text { al. } 2001\end{array}$ \\
\hline $\begin{array}{l}\text { Alpova } \\
\text { diplophloeus }\end{array}$ & OSC 93524 & - & fruitbody & - & AY377571 & $\begin{array}{l}\text { Nouhra et } \\
\text { al. } 2005\end{array}$ \\
\hline $\begin{array}{l}\text { Alpova } \\
\text { diplophloeus }\end{array}$ & OSC 39950 & - & fruitbody & - & AY377572 & $\begin{array}{l}\text { Nouhra et } \\
\text { al. } 2006\end{array}$ \\
\hline Alpova trappei & OSC JMT 16394 & - & fruitbody & - & AF071456 & $\begin{array}{l}\text { Grubisha et } \\
\text { al. } 2001\end{array}$ \\
\hline Alpova trappei & 28042 & - & - & - & KF030307 & $\begin{array}{l}\text { Nuhn et al. } \\
2013\end{array}$ \\
\hline M. broomeanus & BJTC FAN1230-A & Pinus bungeana & fruitbody & China & $\begin{array}{l}\text { Not } \\
\text { submitted }\end{array}$ & In this study \\
\hline M. minobovatus & BJTC FAN911 & Pinus bungeana & fruitbody(holotype) & China & $\begin{array}{l}\text { Not } \\
\text { submitted }\end{array}$ & In this study \\
\hline M. obovatus & BJTC FAN1091 & $\begin{array}{l}\text { in the soil under Quercus variabilis } \\
\text { and Pinus tabuliformis }\end{array}$ & fruitbody(epitype) & China & $\begin{array}{l}\text { Not } \\
\text { submitted }\end{array}$ & In this study \\
\hline M. obovatus & BJTC FAN1208 & $\begin{array}{l}\text { in the soil under Quercus variabilis } \\
\text { and Pinus tabuliformis }\end{array}$ & fruitbody & China & $\begin{array}{l}\text { Not } \\
\text { submitted }\end{array}$ & In this study \\
\hline M. obovatus & BJTC FAN1102-A & Quercus variabilis & fruitbody & China & $\begin{array}{l}\text { Not } \\
\text { submitted }\end{array}$ & In this study \\
\hline M. obovatus & BJTC FAN1102-B & Quercus variabilis & fruitbody & China & $\begin{array}{l}\text { Not } \\
\text { submitted }\end{array}$ & In this study \\
\hline $\begin{array}{l}\text { M. } \\
\text { panzhihuaensis }\end{array}$ & HMAS81915 & Pinus yunnanensis & fruitbody(holotype) & China & $\begin{array}{l}\text { Not } \\
\text { submitted }\end{array}$ & In this study \\
\hline M. quercus & BJTC FAN808 & Quercus sp. & fruitbody & China & $\begin{array}{l}\text { Not } \\
\text { submitted }\end{array}$ & In this study \\
\hline M. spinisporus & BJTC FAN941-A & Ulmus sp. & fruitbody(epitype) & China & $\begin{array}{l}\text { Not } \\
\text { submitted }\end{array}$ & In this study \\
\hline M. spinisporus & BJTC FAN941-B & Ulmus sp. & fruitbody & China & $\begin{array}{l}\text { Not } \\
\text { submitted }\end{array}$ & In this study \\
\hline M. spinisporus & BJTC FAN936-A & Pinus bungeana & fruitbody & China & $\begin{array}{l}\text { Not } \\
\text { submitted }\end{array}$ & In this study \\
\hline M. spinisporus & BJTC FAN936-B & Pinus bungeana & fruitbody & China & $\begin{array}{l}\text { Not } \\
\text { submitted }\end{array}$ & In this study \\
\hline M. tomentellus & BJTC FAN539 & Pinus sp. & fruitbody(epitype) & China & $\begin{array}{l}\text { Not } \\
\text { submitted }\end{array}$ & In this study \\
\hline M. ambiguus & & & & & AF352046 & $\begin{array}{l}\text { Jarosch \& } \\
\text { Besl. } 2001\end{array}$ \\
\hline M. broomeianus & & & & & AF098383 & $\begin{array}{l}\text { Bresinsky et } \\
\text { al. } 1999\end{array}$ \\
\hline Melanogaster sp. & OSC 59776 & & & USA & KT968611 & Unpublished \\
\hline Melanogaster sp. & OSC 59778 & & & USA & KU321864 & Unpublished \\
\hline M. tuberiformis & OSC JMT 9666 & & & & AF074919 & $\begin{array}{l}\text { Grubisha et } \\
\text { al. } 2001\end{array}$ \\
\hline
\end{tabular}




\begin{tabular}{|c|c|c|c|c|c|c|}
\hline Taxon name & Specimen_voucher & Host & Sporocarp/ECM & Origin & $\begin{array}{l}\text { nrDNA- } \\
\text { LSU }\end{array}$ & Study \\
\hline M. tuberiformis & strain 628 & & & & AF167679 & $\begin{array}{l}\text { Jarosch \& } \\
\text { Bresinsky } \\
1999\end{array}$ \\
\hline M. variegatus & & & & Germany & DQ534668 & $\begin{array}{l}\text { Binder \& } \\
\text { Hibbett } \\
2006\end{array}$ \\
\hline Paxillus involutus & RV98.135 & & & & AY612815 & Unpublishec \\
\hline $\begin{array}{l}\text { Uncultured } \\
\text { Alpova }\end{array}$ & clone 1_436 & $\begin{array}{l}\text { Alnus acuminata and Alnus jorullensis } \\
\text { forest (Pinus present) }\end{array}$ & environmental_sample & Mexico & HQ271392 & Unpublishec \\
\hline $\begin{array}{l}\text { Uncultured } \\
\text { Melanogaster }\end{array}$ & 04M7K057 & & environmental_sample_soil & Germany & FR750834 & $\begin{array}{l}\text { Kruger et al. } \\
2012\end{array}$ \\
\hline $\begin{array}{l}\text { Uncultured } \\
\text { Melanogaster }\end{array}$ & H04M7K57 & & environmental_sample_soil & Germany & HF676136 & Unpublishec \\
\hline $\begin{array}{l}\text { Uncultured } \\
\text { Melanogaster }\end{array}$ & $\mathrm{H} 12 \mathrm{M} 7 \mathrm{~K} 29$ & & environmental_sample soil & Germany & HF677077 & Unpublishec \\
\hline
\end{tabular}

\section{Phylogenetic analysis}

Two data sets, ITS and nrLSU, were compiled to identify Melanogaster species and investigate relationships among species. The taxa Gyrodon_lividus, Paxillus_rubicundulus, P._adelphus and Paragyrodon_sphaerosporus were selected as outgroups for ITS Phylogenetic analysis and Paxillus involutus for nrLSU. The ITS and nrLSU sequences were aligned using the MAFFT v.7.110 online program (https://www.ebi.ac.uk/Tools/msa/mafft/) and manually adjusted for maximum similarity in Se-Al version.2.03a. (Rambaut 2000). The datesets were manually edited at misaligned sites. Poorly aligned sites were identified by Gblocks v.0.91b (Castresana 2000; using default options except BAllowed Gap Positions = half) with default parameters. All identified ambiguous sites were excluded before the phylogenetic analysis. We conducted maximum likelihood $(\mathrm{ML})$ and Bayesian inference $(\mathrm{BI})$ analyses on the two data sets. The alignments and phylogenic trees were deposited in TreeBASE (??).

Maximum likelihood (ML) analysis on the dataset was done using RAxML 8.0.14 (Stamatakis et al. 2005; Stamatakis 2006, 2014) and the GTR + G + I substitution model with parameters unlinked. The ML bootstrap replicates (1000) were computed in RAxML using a rapid bootstrap analysis and search for the best-scoring ML tree. The ML trees were viewed with TreeView32 (Page 2001). Clades with bootstrap support (BS) $\geq 70 \%$ were considered significant and highly supported (Hillis and Bull 1993).

Bayesian inference (BI) was performed with MrBayes v3.1.2 (Ronquist and Huelsenbeck 2003) as an additional method of determining branch support.

Bl analyses were performed with MrBayes 3.1.2 (Ronquist and Huelsenbeck 2003) based on the best substitution models determined by MrModeltest 2.3 (Nylander 2004), which were GTR $+I+G$ for the ITS data set and SYM $+I+G$ for the nrLSU data set. Two independent runs of four chains were conducted for 1 400000 (for ITS) and for 580000 (for nrLSU) Metropolis-coupled Markov chain Monte Carlo (MCMCMC) generations with the default setting. The average standard deviations of split frequency (ASDSF) values were far lower than 0.01 at the end of the generations. Trees were sampled every 100 generations after burn-in (well after convergence), and 50\% majority-rule consensus trees were constructed and visualized with TreeView (32 bit) (Page 2001). Clades with Bayesian posterior probability (PP) $\geq 95 \%$ were considered significant (Alfaro et al. 2003).

\section{Results}

\section{Phylogenetic analysis}

The ITS dataset contained 128 sequences (22 generated in this study) and comprised 604 sites, of which 284 were variable sites, and 237 of these variable sites were informative. $\mathrm{ML}$ and $\mathrm{BI}$ analyses produced identical tree topologies, and only the tree derived from the ML analyses is shown (Fig. 1).

The sequences of Melanogaster were grouped into a clade together with 4 sequences labeled as "Alpova trappel" with support values of BS = 77 and PP = 1.00 , then further clustered with the other sequences of Alpova with a strong support value $(B S=100)$. The sequences of $A / p o v a$ employed in this analysis, except the samples of "Alpova trappel", formed two independent clades with strong support. In Melanogaster clade, a total 21 phylotypes (marked A-U) can be recognized based on a species delimitation of $98 \%$ ITS similarity and strong supported clades of the ITS-based ML tree (Fig. 1). Nine of the 21 phylotypes matched known species, while 12 phylotypes represented uncertain or undescribed species, of which 5 species were described and illustrated as new taxa from China in this study. Phylotype A was designated as $M$. intermedius as it contained 2 reliably identified sequences EU784372 and EU784371 of $M$. intermedius published by Brock et al. (2009), and had a strong support (BS = 97/PP = 1.00); Phylotype B contained 2 ectomycorrhizal (ECM) sequences of USA and Canada, one environmental sequence of Canada and 3 sequences of inaccurately identified specimens from USA, showed more than $98.18 \%$ ITS similarity among them and less than $97.23 \%$ ITS similarity with other phylotypes. It also had a strong support (BS $=99 / \mathrm{PP}=1.00)$ and could represent a new taxon from North America, marked M. sp.1 here (Fig. 1); Phylotype C contained 4 sequences, 2 from ECM and environmental sample respectively, one labeled as Melanogaster ambiguus from a unpublished study and one sequence was newly obtained in the present work from a specimen of $M$. ambiguus (collected 
by Richard in Wiltshire, UK, 1987). These sequences showed more than $99.26 \%$ ITS similarity and less than $97.91 \%$ ITS similarity with other phylotypes, with a moderate support value ( $\mathrm{BS}=75$ ). Combined the morphologic features of the specimen of $M$. ambiguus we therefore recognized phylotype $\mathrm{D}$ as $M$. ambiguus. Phylotype D contained 4 sequences labeled as Melanogaster ambiguus and $M$. broomeanus from an unpublished study about Hungary specimens. These sequences showed more than $99.02 \%$ ITS similarity and less than $97.9 \%$ ITS similarity with other phylotypes, with a strong support (BS $=94 / \mathrm{PP}=1.00)$. It could represent a new taxon from Hungary, marked M. sp.2 here; Phylotype E contained one ECM sequences from Poland and 2 sequences of inaccurately identified specimens of Hungary. The 3 sequences showed more than $99.29 \%$ ITS similarity among them and less than $97.74 \%$ with other phylotypes. It could represent a new taxon from Central Europe, marked $M$. sp.3 here; Phylotype F was designated as $M$. euryspermus. For it contained one sequence of $M$. euryspermus pubilished by Frank et al. (2006), and the sequence showed less than $94.53 \%$ ITS sequence similarity to other Melanogaster species; Phylotype G and $\mathrm{N}$ contained one sequence respectively, a sequence (JN022515) of inaccurately identified specimen of USA, and an unpublished ECM sequence (JN198097). The 2 sequences showed $94.53 \%$ ITS similarity to each other even with other species of Melanogaster. The 2 phylotypes could be new taxa of Melanogaster, marked M. sp.4 and M. sp.5 respectively; Phylotype H contained 8 sequences obtained from several new collections of Shanxi Province, China, which were identified as $M$. spinisporus morphylogically in this study. The sequences shared more than $98.78 \%$ ITS similarity, and less than $92.03 \%$ ITS similarity to other phylotypes, convincing us that it was a distinct species. Therefore, we recognized phylotype $\mathrm{H}$ as $\mathrm{M}$. spinisporus, Phylotype I contained 3 sequences obtained from 3 specimens newly collected from Shanxi Province, which was different from all of known species of Melanogastermorphylogically. The sequences showed more than $99.35 \%$ ITS similarity among them and less than $97.9 \%$ ITS similarity to other phylotypes. For this, the new taxon $M$. obovatus was proposed in the present study; Phylotype $J$ contained 2 sequences obtained from 2 specimens newly collected from Shanxi Province, China, which could be distinguished from other species of Melanogaster morphylogically. The sequences showed more than $99.75 \%$ ITS similarity among them and less than $97.9 \%$ ITS similarity to other phylotypes. Therefore, the new taxon M. quercus was proposed for it; Phylotypes $\mathrm{K}$ and M contained one sequences newly extracted from holotypes of Chinese species $M$. shanxiensis and M. subglobisporus respectively. The two sequences showed less than $97.91 \%$ and 92.24 ITS similarity to other phylotypes respectively, clarifing their phylogenetic positions. Therefore, phylotypes $\mathrm{K}$ and $\mathrm{M}$ were identified $M$. shanxiensis and M. subglobisporus respectively; Phylotype L contained one sequence extracted from the specimen (BJTC FAN539) newly collected in Yunnan province, China, which was distinguished from other species of Melanogaster obviously in morphology. The sequence showed less than $95.33 \%$ ITS sequence similarity to other phylotypes, indicating it is a distinct species in Melanogaster. And the new species M. tomentellus was thus proposed for it; Phylotype 0 contained 15 sequences, including the holotype sequence (NR_132848) of M. rivularis, showed more than $99.02 \%$ ITS similarity among each other and less than 96.76 ITS similarity to other species of genus Melanogaster. Therefore, phylotype 0 was designated as $M$. rivularis with no doubt; Phylotype P contained 11 sequences, including two sequences (HQ714780, HQ714794) from accurately identified specimens of M. luteus published by Moreau et al. (2011), showed more than $99.41 \%$ ITS similarity among each other and less than $97.07 \%$ ITS similarity to other species of genus Melanogaster. For the above reasons, phylotype P was recognized as M. luteus, Phylotype Q was designated as $M$. broomeanus, containing11 sequences of which 3 sequences were newly obtained from the specimens of China in this work and a reliably identified sequence of $M$. broomeanus (EU784370) published by Brock et al. (2009). The 11 sequences showed more than $98.09 \%$ ITS similarity and less than $95.73 \%$ ITS similarity to other species of Melanogaster. Consequently, we recognized phylotype Q as $M$. broomeanus based on morphology and phylogenetic analysis; Phylotype R contained only a sequence from ectomycorrhizae (ECM) of Quercus liaotungensis Koidz in China, shared less than $94.79 \%$ ITS similarity to other species of Melanogaster. It should represent a potential new taxon from China, marked M. sp.6 here; Phylotype S contained 7 sequences of USA, one sequence from ECM of Lithocarpus densiflorus and 4 sequences extracted from the specimens labeled as "Alpova trappel". Evidently, these sequences of "Alpova trappel" did not cluster with Alpova sequences in this analysis, implying they represented the Melanogaster species rather than Alpova species. Thus Phylotype S could represent a potential new taxon of Melanogaster from USA, marked M. sp.7 here; Phylotype T contained 2 sequences, one extracted from the specimen (BJTC FAN911) newly collected in Shanxi province, China and another sequences (JQ318611) obtained from ectomycorrhizae of Quercus liaotungensis in Loess Plateau, China. They showed 99\% ITS sequence similarity and less than 91.72\% ITS similarity to other species of Melanogaster, for which a new species M. minobovatus was proposed; Phylotype U was represented by one sequence newly obtained from the specimen of Sichuan province, China, which was significantly different from other species of Melanogaster morphologically. In addition, the sequence showed less than $89.89 \%$ to other species of genus Melanogaster, indicating it was a distinct species. Thus, $M$. panzhihuaensis was proposed for it.

Phylogeny based nrLSU sequences were analyzed because there were the samples of Alpova trappei grouped into Melanogaster clade rather than Alpova clade in ITS-based phylogeny although there were a small number of available sequences. The nrLSU dataset contained 35 sequences (14 generated in this study) and comprise772 sites, of which 103 variable sites, and 64 of these variable sites were informative. ML and BI analyses produced identical tree topologies, and only the tree derived from the ML analyses is shown (Fig. 2). Two clades were recognized in this tree, respectively representing Melanogaster and Alpova, and the sequences labeled as "Alpova trappel" (marked with pentagram ( $($ ) symbol) were placed in Melanogaster clade rather than Alpova clade, consistent with that of the ITS-based phylogenetic analysis (Fig. 1). The other sequences of Alpova cluster an independent clade with a strong support clade $(B S=97, \mathrm{PP}=1.00)$. These further confirmed that the samples of Alpova trappei represented the species of the genus Melanogaster. Moreover, the Chinese Melanogaster sequences were grouped in Melanogaster clade as those observed on the ITS tree (Fig. 1).

\section{Taxonomy}

Melanogaster broomeanus Berk., in Montagne, Annls Sci. Nat., Bot., sér. 2 20: 377 (1843) Fig. 3, a-f

三Melanogaster ovoidisporus var. angustatisporus K. Tao, Ming C. Chang \& B. Liu, Journal of Shanxi University, Natural Science 18(4): 449 (1995). syn. nov. Type:-CHINA. SHANXI PROV.: Jincheng City, Yangcheng County, Mang River National Nature Reserve, in soil under Quercus sp., 29 May 1988, M.-c. Chang 222 (HMAS83258 ex MHSU2022).

\section{Description}


Basidiomata 1.5-2.5 $\times 2-2.5 \mathrm{~cm}$, hypogeous, subglobose to irregularly globose, yellow-brown, becoming blackish where handled, without distinct basal zone; rhizomorphs few, brown; odor no record. Gleba yellow brown when fresh, black when dry, with sterile white veins scattered throughout. Peridium single-layered, 150-400 $\mu \mathrm{m}$ thick, composed of hyphae, hyphae generally parallel to the surface of peridium but loosely interwoven, pale yellow to whitish, $5-12.5 \mu \mathrm{m}$ in diam, clamp connections abundant; Trama plates of hyaline interwoven hyphae, 2.5-5 $\mu \mathrm{m}$ in diam, thin-walled, tending to be gelatinized. Basidia $16.5-22.2 \times$ 5.0-6.7 $\mu \mathrm{m}$, light yellow clavate-capitate when young, 4-spored, sterigmata short, collapsed and disappeared at maturity. Basidiospores ellipsoid or oblong to cylindrical, 4.4-7.8 × 3.3-4.7 $\mu \mathrm{m}(\mathrm{avX}=6.0 \pm 1.0 \times 3.9 \pm 0.36, \mathrm{n}=50), \mathrm{Q}=1.3-1.9(\mathrm{avQ}=1.5 \pm 0.2, \mathrm{n}=50)$, deep brown at maturity, walls $0.5 \mu \mathrm{m}$ thick, smooth, apex obtuse, the base broadly truncate-cupped, with very short remnants of sterigmata.

\section{Habit, habitat and distribution}

July to September, in soil under Quercus liaotungensis, Pinus bungeana Zucc. ex Endl., Lonicera japonica Thunb. Warm temperate zone and cold temperate zone of North China.

Notes: Melanogaster broomeanus is diagnosed by its yellow-brown basidiomata, single-layered peridium composed of interwoven hyphae, light brown ellipsoid or oblong to cylindrical basidiospores. The specimens (BJTC FAN909, BJTC FAN1230), newly collected from Shanxi Province, China, morphologically fit well with the characteristics of $M$. broomeanus, and phylogenetically their ITS sequences were clustered in the M. broomeanus clade with strong support (BS $=99 / \mathrm{PP}=1.00)$ (Fig. 1), suggesting the two Chinese collections represented the Europe species M. broomeanus. M. ovoidisporus var. angustatisporus is described by Wang et al. (1995) based on the specimens from Chinese Shanxi Province, but their morphological traits described by authors is very similar to M. broomeanus. In this study, we re-examined the morphology of holotype and paratypes cited by Wang et al. (1995), and compared them with our new collections (BJTC FAN909, BJTC FAN1230) from Shanxi Province, and as a result, there are not any obvious differences to be revealed among these specimens in morphology. Unfortunately, the DNA sequences of those old specimens are not sequenced successfully, but combining the features of morphology and geography, we conclude that $M$. ovoidisporus var. angustatisporus should be considered synonym of $M$. broomeanus.

Material examined: CHINA. SHANXI PROV.: Jincheng City, Yangcheng County, Sanglin Village, Shupigou, in soil under Lonicera japonica Thunb., Alt. 860 m, 27 August 1987, M.-c. Chang 242 (HMAS81917 ex MHSU2023); Linfen City, Xi County, Shenjiagou, in soil under Quercus liaotungensis, Alt. 1321 m, 10 September 2017, Y.-y. Xu 033 (BJTC FAN909); ibid., in soil under Pinus bungeana, X.-y. Yan 155 (BJTC FAN1230); Yuncheng City, Yuanqu County, Lishan Village, 25 July 1987, M.-c. Chang 505 (HMAS83323 ex MHSU2002); ibid., Alt. 1280 m, 8 August 1990, Y. Ma, B. Qiao, W.-k. Bai 502 (HMAS96692 ex MHSU2003). SICHUAN PROV:: Songpan County, Alt. 3100 m, 30 August 1991, M.-s. Yuan 1729 (HKAS24811).

Melanogaster fusisporus Y. Wang, in Wang, Chang, Tao \& Liu, Journal of Shanxi University, Natural Science 18(4): 450 (1995) Fig. 3, g-j

\section{Description}

Basidiomata 1.1-1.6 × 1.2-3 cm, hypogeous, subglobose to irregularly globose, yellow brown to brown, without distinct basal zone; rhizomorphs few, brown; sweet odor, such as the banana flavor or the apple flavor. Gleba deep brown when fresh, black after dried, with sterile white veins scattered throughout. Peridium two-layered, epicutis 10-20 $\mu \mathrm{m}$ thick, composed of interwoven hyphae, light orange yellow, 4-5 $\mu \mathrm{m}$ in diam, smooth; subcutis $230-400 \mu \mathrm{m}$ thick, composed of interwoven hyphae, with abundant inflated cells, irregular or puzzle-like, up to 5-40 $\mu \mathrm{m}$ wide, yellowish to pale orange yellowto ward outside surface; Trama plates of interwoven hyphae, hyaline to light yellow, thin-walled, $3-4 \mu \mathrm{m}$ in diam, tending to be gelatinized. Basidia $9-12 \times 10-23 \mu \mathrm{m}$, hyaline clavate-capitate when young, 2-3-spored, sterigmata short, collapsed and disappeared at maturity. Basidiospores fusiform, apex bluntly apiculate, $10.0-15.9$ $\times 4.8-6.3 \mu \mathrm{m}(\operatorname{avX}=12.3 \pm 1.4 \times 5.2 \pm 0.3, \mathrm{n}=50), \mathrm{Q}=2.0-2.9(\mathrm{avX}=2.3 \pm 0.2, \mathrm{n}=50)$, orange brown or deep brown at maturity, $1 \mu \mathrm{m}$ thick, smooth, the base broadly truncate-cupped, with very short remnants of sterigmata.

Habit, habitat and distribution: August to September, in soil under Quercus moglica Fish., Q. acutissima Carr. Northeast and South China.

Notes: Melanogaster fusisporus is re-described in details based on the re-examinations for paratypes cited by Wang et al. (1995) and newly added specimen HMAS83274 from type location. In this study, the beautiful illustrations were provided, intuitively presented the shape of the fusiform spore to people. The newly added specimen, HMAS83274 ex MHSU2008 used to be cited as Melanogaster fusisporus var. obovatus (this variety has been revised to Melanogaster obovatus based on present study.) in Flora Fungorum Sinicorum (Vol.7) (Liu et al. 1998). Although we sequenced unsuccessfully, we noticed this specimen was mature and fitted well with M. fusisporus in morphyology, besides it was collected from type location in Chinese Yunnan Provence. For the above reasons, we diagnosed this specimen as M. fusisporus. Melanogaster fusisporus is diagnosed by its fusiform basidiospores with a bluntly apiculate apex, orange brown or deep brown basidiospores at maturity, easy to be recognized. Melanogaster quercus differs from M. fusisporus by its brick red basidiomata and light yellowish basidiospores of $10.8-15.3 \times 5.6-7.7 \mu \mathrm{m}$.

Material examined: CHINA. HEILONGJIANG PROV.: Ningan City, Jingpo Lake, in soil under Quercus monglica, 12 Sept 1987, K. Tao, L. Fan 193 (HMAS83095 ex MHSU2004, paratype); YUNNAN PROV.: Kunming City, Heilongtan, Kunming Botanical Garden, in soil under Q. acutissima, 10 August 1990, M.-c. Chang, L. Wang, D.-s. Wang 239 (HMAS96755 ex MHSU2005, paratype); ibid., M.-c. Chang, L. Wang 224 (HMAS83274 ex MHSU2008).

Melanogaster minobovatus L. Fan \& X.Y. Yan sp.nov. MycoBank MB Fig. 3, k-n

Etymology: minobovatus, min, minor, obovatus, obovoid, referring to the size and shape of basidiospores.

Type: CHINA. SHANXI PROV.: Linfen City, Xi County, shenjiagou, in soil under Pinus bungeana, Alt. 1321 m, 10 Sept 2017, Y.-y. Xu 035 (BJTC FAN911). 


\section{Description}

Basidioma $3.5 \times 4.5 \mathrm{~cm}$, hypogeous, subglobose, yellow-brown, without distinct basal zone; rhizomorphs invisible, Strong wine aroma or fruit aroma. Gleba black, liquefying to produce a very dark spore mass. Peridium two-layered, 20-50 $\mu \mathrm{m}$ thick, composed of interwoven hyphae, 4-7 $\mu \mathrm{m}$ in diam, smooth, clamp connections abundant; subcutis 300-450 $\mu \mathrm{m}$ thick, composed of interwoven hyphae, with a large number of inflated cells, ellipsoidal, irregular or puzzle-like, up to 6.5-17 $\mu \mathrm{m}$ wide, light yellowish to yellow toward outside surface. Trama plates of hyaline gelatinized hyphae. Basidia not observed. Basidiospores obovoid, $5.1-6.9 \times 4.2-5.1 \mu \mathrm{m}$ ( $\mathrm{avX}=6.1 \pm 0.4 \times 4.7 \pm 0.2, \mathrm{n}=50$ ), $\mathrm{Q}=1.1-1.5$ (avX=1.3 $\pm 0.1, \mathrm{n}=50$ ), deep brown at maturity, $0.5-1 \mu \mathrm{m}$ thick, smooth, the base truncate-cupped, with very short remnants of sterigmata.

Habit, habitat and distribution: September, in soil under Pinus bungeana. Warm temperate zone of North China.

\section{Notes}

This species is distinguished from other Melanogaster species by its basidioma with strong wine aroma or fruit aroma, and small, obovoid and deep brown basidiospores. Melanogaster minisporus Cázares, Guevara, described from Mexico by Cázares et al. (2008), is similar to M. minobovatus in basidiospore shape and size. However, M. minisporus differs from M. minobovatus in its bright yellow basidiomata and dark brown gleba with white or yellow at maturity. Phylogenetically, an environmental sequence (Genbank accession JQ318611) associated with Quercus liaotungensis from Loess Platea, China was grouped a strong support clade $(B S=100, P P=1.00)$ together with $M$. minobovatus (Fig. 1), and both of them shared $99 \%$ ITS similarity from each other, which supported that M. minobovatus is a distinct species, and is associated to Quercus sp. and Pinus sp.

Melanogaster obovatus (K. Tao, Ming C. Chang \& B. Liu) L. Fan \& X.Y. Yan comb. \& stat. nov. MycoBank MB Fig. 3, o-r

=Melanogaster fusisporus var. obovatus K. Tao, Ming C. Chang \& B. Liu, Journal of Shanxi University, Natural Science 18 (4): 450 (1995).Type:-CHINA. SHANXI PROV.: Yucheng City, Yuanqu County, Lishan Town, Houwentang Village, in soil under Spiraea pubescens Turcz., 2 August 1990, M.-c. Chang 193 (HMAS83257 ex MHSU1470).

Diagnosis: Melanogaster obovatus is diagnosed by its light brick red or orange brown basidiomata, yellow green to yellow brown gleba, elongate-fusiform with rounded top to obovate and light yellow brown basidiospores. Melanogaster fusisporus differs from M. obovatus by its black gleba at maturity, fusiform with acute apex and dark brown basidiospores of (10-)11.5-13(-15)×(5-)5.5-6(-6.5) $\mu \mathrm{m}$. Melanogaster intermedius (Berkeley) Zeller \& Dodge, described from England and Amercia, is somewhat similar to M. obovatus in basidiomata appearance. However, $M$. intermedius is distinguished from $M$. obovatus by its thin peridium of $125-160 \mu \mathrm{m}$, slaty black gleba and wide basidiospores of $11-13 \times 7.4-8 \mu \mathrm{m}$.

\section{Description}

Basidiomata 1.5-2.3 $\times 0.7-1.5 \mathrm{~cm}$, hypogeous, subglobose, light brick red or orange brown, minutely tomentose, without distinct basal zone; rhizomorphs few, brown; sweet odor, like fruits flavor. Gleba gelatinous, yellow green to yellow brown, with sterile white veins scattered throughout, liquefying to become the slimy spore mass at maturity. Peridium two-layered, epicutis 50-100 $\mu \mathrm{m}$ thick, composed of interwoven hyphae, yellow brown, 4-10 $\mu \mathrm{m}$ in diam, smooth, clamp connections abundant; subcutis 300-500 $\mu \mathrm{m}$ thick, composed of interwoven hyphae, with massive inflated cells, ellipsoidal, irregular, up to $10-32 \mu \mathrm{m}$ wide, yellowish to yellow brown toward outside surface. Trama plates of hyaline or yellowish gelatinized hyphae. Basidia 10-14.2× 4.9-6.7 $\mu$ m, light yellow clavate-capitate when young, 4-spored, sterigmata short, collapsed and disappeared at maturity. Basidiospores elongate-fusiform with rounded top to obovate, $10.3-14.8 \times 4.6-7.3 \mu \mathrm{m}(\mathrm{avX}=12.2 \pm 0.9 \times 6.0 \pm 0.4, \mathrm{n}=50), \mathrm{Q}=1.7-2.6$ (avQ $=2.1 \pm 0.2, \mathrm{n}=50$ ), light yellow brown, walls $0.5 \mu \mathrm{m}$ thick, smooth, the base broadly truncate-cupped, with very short remnants of sterigmata.

\section{Habit, habitat and distribution}

June to September, in soil under Quercus sp., Pinus tabuliformis Carr. Temperate zone of North and Northeast China.

\section{Notes}

Phylogenetic analysis based on the sequences of specimens newly collected from type locality and morphologically consistent with the type specimen of $M$. fusisporus var. obovatus, revealed that these sequences clustered the independent clade $\mathrm{J}$ with a strong support (BS $=96 / \mathrm{PP}=1.00)$ (Fig. 1 ), supporting they represented a distinct species. Therefore, we raised $M$. fusisporus var. obvatus to species level as $M$. obvatus, and an epitype (BJTC FAN1091) was designated here. Phylogenetically, M. quercus and $M$. shanxiensis were related to M. obovatus closely. However, they morphologically differed from $M$. obovatus in black gleba and elongate-fusiform spores with apiculate apex for the former and white to pale yellow basidioma and elongate-obovatus basidiospores for the latter.

Material examined: CHINA. JILIN PROV.: Dunhua city, Dashitou county, under Quercus mongolica Fisch. ex Ledeb., 15 September 1987, L. Fan, K. Tao 226 (HMAS83269 ex MHSU2010). SHANXI PROV.: Jinzhong city, Lingshi county, Houhuigou, 27 June 1987, under Q. liaotungensis Koidz., T.-I. Shangguan 234 (HMAS81918 ex MHSU2015); Yuncheng City, Yuanqu county, Lishan Town, Houwentang Village, Alt. 1280 m, 2 August 1990, Y. Ma, B. Qiao, X.-k. Bai 198 (HMAS83094 ex MHSU2006); ibid., X.-k. Bai, B. Qiao, Y. Ma 215 (HMAS83267 ex MHSU2007); ibid., Y. Ma, B. Qiao, X.-k. Bai 225 (HMAS83265 ex MHSU2009); ibid., Y. Ma, X.-k. Bai, B. Qiao 227 (HMAS83266 ex MHSU2011); ibid., B. Qiao, Y. Ma, X.-k. Bai 501 (HMAS83268 ex MHSU2018); ibid., 1 August 1990, Y. Ma, X.k. Bai, B. Qiao 231 (HMAS83270 ex MHSU2014); ibid., Y. Ma, B. Qiao, X.-k. Bai 503 (HMAS83272 ex MHSU2019); ibid., under Q. liaotungensis, 27 July 1987, 
M.-c. Chang 228 (HMAS83271 ex MHSU2012); ibid., Alt. 1900 m, 24 July 1987, M.-c. Chang 230 (HMAS83264 ex MHSU2013); ibid., 20 July 1987, M.-c. Chang, Y.-h. Chang 240 (HMAS83273 ex MHSU2017); ibid., 25 July 1987, M.-c. Chang 236 (HMAS83275 ex MHSU2016); Yuncheng City, Xia County, Sijiao Town, Yujialing Village, Alt. 970 m, 27 Octomber 2017, in soil under Q. variabilis, T. Li 055 (BJTC FAN1081); ibid., X.-y. Yan 123 (BJTC FAN1091, epitype, designated here); in soil under Q. variabilis BI., Y.-y. Xu 072 (BJTC FAN1102-A); ibid., Y.-y. Xu 072 (BJTC FAN1102-B); ibid., in soil under Pinus tabuliformis, K.-b. Huang 156 (BJTC FAN1118); ibid., 19 August 2019, in soil under Quercus sp., Y.-y. Xu 150 (BJTC FAN1208).

Melanogaster panzhihuaensis L. Fan \& X.Y. Yan sp.nov. MycoBank MB Fig. 3, s-v

Etymology. panzhihuaensis, referring to the type locality, where the type was collected.

Type: CHINA. SICHUAN PROV.: Panzhihua City, in soil under Pinus yunnanensis Franch., 1995, Z.j. Gu 6 (HMAS 81915 ex MHSU2266).

Diagnosis: Melanogaster panzhihuaensis is diagnosed by its oval basidiospores with blunt and narrow apex and reddish brown basidiospores at maturity.

Description: Basidioma1.5 $1.7 \mathrm{~cm}$, hypogeous, subglobose, brown to dark brown when dry; no rhizomorphs visible; odor no record. Gleba pale yellow-brown when fresh, firm, black after dried, with sterile white veins scattered throughout. Peridium single-layered, $150-220 \mu \mathrm{m}$ thick, compactly interwoven hyphae, $2.5-5 \mu \mathrm{m}$, with a large number of inflated cells, puzzle-like or irregular, up to $7.5-13 \mu \mathrm{m}$ wide, light yellowish to yellow walls toward surface. Trama plates of interwoven hyphae, pale orange-yellow, thin-walled, $2-5 \mu \mathrm{m}$ in diam. Basidia not observed. Basidiospores oval, apex blunt and narrow, 8.7-12.4 $\times 5.2-7.6 \mu \mathrm{m}$ ( $a v X=10.4 \pm 0.8 \times 6.1 \pm 0.6, n=45), Q=1.4-2.0(a v X=1.7 \pm 0.2, n=45)$, reddish brown, the base truncate-cupped, walls $1 \mu m$ thick, smooth, the base broadly truncate-cupped, with very short remnants of sterigmata.

\section{Habit, habitat and distribution}

in soil under Pinus yunnanensis, Southwest China.

\section{Notes}

In present study, the sequence of M. panzhihuaensis showed less than $89.89 \%$ ITS similarity to other species and formed an independent clade $U$ (Fig. 1), indicating it was a distinct species. In addition, the sequences of M. minobvatus formed sister clade with M. panzhihuaensis. However, M. minobvatus is differentiated from M. panzhihuaensis by its yellow-brown basidiomata, obovoid and small basidiosporesof 5.1-6.9 × 4.2-5.1 $\mu \mathrm{m}$. Morphyologically, Melanogaster natsii is similar to M. panzhihuaensis in the color of gleba, but $M$. natsii differs from the latter in its broadly citriform or obovatus and pale yellow brown basidiospores.

Melanogaster quercus L. Fan \& X.Y. Yan sp.nov. MycoBank MB Fig. 4, a-d

Etymology: quercus, referring to the host of this species.

Type: CHINA. SHANXI PROV.: Lvliang City, Jiaocheng County, Pangquangou, in soil under Quercus sp., Alt. 1879 m, 6 September 2017, Y.-y. Xu 011 (BJTC FAN809).

Diagnosis: Melanogaster quercus is diagnosed by brick red appearance, black gleba and light yellow elongate-fusiform basidiospores with apiculate apex. $M$. obovatus is closely related to M. quercus. However, M. obovatus differs from M. quercus in its yellow green to yellow brown gleba and elongate-fusiform with rounded top to obovate spores.

Description: Basidiomata 1.8-2 × 2-2.5 cm, hypogeous, subglobose, brick red, without distinct basal zone; no rhizomorphs visible; slightly sweet odor. Gleba gelatinous-firm, black, irregular glebal chambers separated by sterile white veins. Peridium two-layered, epicutis $50-100 \mu \mathrm{m}$ thick, composed of interwoven hyphae, yellow, 4.5-10 $\mu \mathrm{m}$ in diam, clamp connections visible; subcutis 400-500 $\mu \mathrm{m}$ thick, composed of interwoven hyphae, with massive inflated cells, ellipsoidal, puzzle-like or irregular, 10-50 $\mu \mathrm{m}$, thin-walled, yellowish to yellow toward ouside surface. Trama plates of hyaline or yellowish gelatinized hyphae. Basidia not observed. Basidiospores elongate-fusiform, apex apiculate, 10.8-15.3 ×5.6-7.7 $\mu \mathrm{m}(\operatorname{avX}=13.1 \pm 1.1 \times 6.5 \pm 0.5, \mathrm{n}=50$ ), $\mathrm{Q}=1.6-2.4$ (avX $=2.0 \pm$ $0.2, n=50$ ), light yellowish, $0.5 \mu \mathrm{m}$ thick, smooth, the base truncate-cupped, with very short remnants of sterigmata.

\section{Habit, habitat and distribution}

September, in soil under Quercus sp. Warm temperate zone of North China.

\section{Notes}

Phylogenetically, the sequences of Melanogaster quercus clustered together and branched as the sister group to the sequence of $M$. shanxiensisis with no support value, implying that $M$. quercus is a distinct species and related to $M$. shanxiensisis. However, M. shanxiensis differs from M. quercus in its white to pale yellow basidiomata and elongate-obovate basidiospores. Morphyologically and phylogenetically, M. obovatus is closely related to $M$. quercus. However, M. obovatus differs from M. quercus in its yellow green to yellow brown gleba and elongate-fusiform with rounded top to obovate spores. In addition, the 
sequences of the two species were grouped in two different branches $(I$ and $J)$ with a high support value $(B S=95 / P P=0.95)$ and $(B S=99 / P P=1.00)$ respectively.

Material examined: CHINA. SHANXI PROV.: Lvliang City, Jiaocheng County, Pangquangou, in soil under Quercus sp., Alt. 1879 m, 6 September 2017, Y.-y. Xu 010 (BJTC FAN808); ibid., in soil under Q. liaotungensis, T. Li 015 (BJTC FAN832).

Melanogaster shanxiensisi B. Liu, K. Tao \& Ming C. Chang, Acta Mycol. Sin. 8(3): 210 (1989) Fig. 4, e-h

Description: Basidiomata 2-2.9 × 1.5-1.8 cm, hypogeous, subglobose, white to pale yellow when fresh, without distinct basal zone, smooth to minutely tomentose when dry; rhizomorphs visible; odor no record. Gleba firm, pale brown when young to brown to brownish black when mature, irregular glebal chambers separated by sterile yellowish brown veins. Peridium two-layered, epicutis 30-70 $\mu \mathrm{m}$ thick, composed of interwoven hyphae, deeply orange-yelow, 5.0-5.5 $\mu \mathrm{m}$ in diam, clamp connections visible; subcutis 150-350 $\mu \mathrm{m}$ thick, composed of interwoven hyphae, with massive inflated cells, ellipsoidal to irregular, 7-25 $\mu \mathrm{m}$, thin-walled, yellowish to yellow toward ouside surface. Trama plates of hyaline or yellowish gelatinized hyphae. Basidia not observed. Basidiospores elongate-obovate to narrowly oblong, apex obtuse, $10.5-14.5 \times 5.0-6.5 \mu \mathrm{m}(\mathrm{avX}=12.2 \pm 1.0 \times 6.1 \pm 0.4, \mathrm{n}=50), \mathrm{Q}=1.6-2.3(\mathrm{avX}=2.0 \pm 0.2, \mathrm{n}=$ 50), light yellow brown, $1 \mu \mathrm{m}$ thick, smooth, the base truncate-cupped, with very short remnants of sterigmata.

\section{Habit, habitat and distribution}

September, in soil under Lespedeza bicolor Turcz. Warm temperate zone of North China.

\section{Notes}

Melanogaster shanxiensisi can be easily distinguished from other Melanogaster species by its white to pale yellow basidiomata and yellow brown elongateobovate to narrowly oblong basidiospores 10.5-14.5 × 5.0-6.5 $\mu \mathrm{m}$. In present study, the sequence newly obtained from holotype (HMAS81910) of Melanogaster shanxiensisis showed less than $97.91 \%$ ITS similarity to other species, indicating it is a distinct species. Phylogenetic analysis reveals this sequence is sister clustered with M. quercus with no support value, implying that $M$. shanxiensisis is a distinct species and related to $M$. quercus. Morphyologically, M. quercus are differentiated from M. shanxiensisi by brick red basidiomata and elongate-fusiform basidiospores.

Material examined. CHINA. SHANXI PROV.: Yuncheng City, Yuanqu County, Lishan township, in soil under Lespedeza bicolor Turcz., 10 September 1987, M.-C. Chang 197 (HMAS81910 ex MHSU909, Holotype).

Melanogaster spinisporus Y. Wang, in Wang, Chang, Tao \& Liu, Journal of Shanxi University, Natural Science 18(4): 450 (1995), emend. L. FAN \& X.Y. Yan Fig. $4, i-n$

\section{Description}

Basidiomata 3-3.5 $\times 4-5 \mathrm{~cm}$, hypogeous, sometimes exposed, subglobose, lignt brown with some red brown or brick red when fresh, light brown to brown when dry, without distinct basal zone; rhizomorphs few, brown; strong wine aroma. Gleba dark red-brown to black when fresh, firm, gelatinous, with sterile white veins scattered throughout, trend toward liquefaction, black and hard when dry. Peridium single-layered, $360-750 \mu \mathrm{m}$ thick; compactly interwoven hyphae, 5-7.5 $\mu \mathrm{m}$ in diam, thin-walled, light yellowish or yellow, clamp connections abindant. Trama plates of gelatinized hyphae. Basidia $23.0-36.5 \times 8.0-$ $14.5 \mu \mathrm{m}$, light brown clavate-capitate when young, 4-spored, sterigmata short, collapsed and disappeared at maturity. Basidiospores broadly ellipsoid to obovoid, subglobose, bilaterally symmetric, appearing smooth or decorated with sparse spine under light microscope (LM), $0.5-1 \mu \mathrm{m}$ high, short strip, even connected into small pieces, irregularly verrucose under scanning electron micro-scope (SEM); 7.4-12.0 $\times 5.2-9.2 \mu \mathrm{m}(\mathrm{avX}=9.6 \pm 1.0 \times 7.3 \pm 0.7, \mathrm{n}=50), \mathrm{Q}=$ 1.1-1.7 (avX $=1.3 \pm 0.1, n=50)$, deep brown at maturity, walls $0.5-1 \mu \mathrm{m}$ thick the base truncate-cupped, with very short remnants of sterigmata.

\section{Habit, habitat and distribution}

Summer and Autumn (July, September to October), in soil under Quercus sp, Pinus bungeana, sometimes exposed. Warm temperate zone of North China.

Notes. Melanogaster spinisporus is diagnosed by its light brown with some red brown or brick red tints basidiomata, broadly ellipsoid to obovoid or subglobose basidiospores, decorated with short strip, even connected into small pieces, irregularly verrucose under SEM. Melanogaster spinisporus was original described obovoid spore, spinose and spine $0.5 \mu \mathrm{m}$ high by Wang et al. (1995). However, we checked the holotype of Melanogaster spinisporus (HMAS27263 collected from Beijing of China in 1958 by Shuqun Deng), confirmed the spore ornamented by verrucose under SEM, but failed to obtain sequence. Phylogenetic analysis based on the sequences of specimens (BJTC FAN936, BJTC FAN938, BJTC FAN941, BJTC FAN1085, BJTC FAN1092) newly collected from Shanxi Province and morphologically consistent with the type specimen of $M$. spinisporus revealed that these sequences clustered in independent clade $\mathrm{H}$ with a strong support (BS = 99/PP = 1.00), supporting they represented a distinct species (Fig. 1). Therefore we recognized it as $M$. spinisporus, emended the description and an epitype (BJTC FAN941-A) was designated here. Phylogenetically, M. obovatus, M. quercus, M. shanxiensis, M. tomentellus were related to $M$. spinisporus. However, the formers could be distinguished obviously from the latter by their smooth elongate-fusiform or elongate-obovate spores. Morphologically, Melanogaster utriculatus Y. Wang, Castellano \& Trappe have obovatus basidiospores with decoration described by Wang et al. (2005) from Japan is similar to M. spinisporus. However, M. utriculatus differs from M. spinisporus by its bigger spores (9-)11-15(-17) × (7-)8$11 \mu \mathrm{m}$ and appressed or inflated utricle on the spore surface . 
Material examined: CHINA. BEIJING: Beijing City, Mentougou District, Tantuo Temple, on the ground of Quercus sp. forest, July 1958, S.-q. Teng 4809 (HMAS27263, Holotype). SHANXI PROV.: Linfen City, Xi County, shenjiagou, in soil under Pinus bungeana, Alt. 1321 m, 10 September 2017, K.-b. Huang 110 (BJTC FAN936-A); ibid., K.-b. Huang 110 (BJTC FAN936-B); ibid., K.-b. Huang 110 (BJTC FAN936-C); ibid., Alt. 1326 m, in soil under Pinus bungeana, K.-b. Huang 112 (BJTC FAN938); ibid., K.-b. Huang 115 (BJTC FAN941-A, epitype, designated here); ibid., K.-b. Huang 115 (BJTC FAN941-B); Yuncheng City, Xia County, Sijiao Town, Yujialing Village, in soil under Quercus variabilis, Alt. 970 m, 27 October 2017, T. Li 059 (BJTC FAN1085); ibid., X.-y. Yan 124 (BJTC FAN1092).

Melanogaster subglobisporus K. Tao, Ming C. Chang \& B. Liu, in Wang, Chang, Tao \& Liu, Journal of Shanxi University, Natural Science 18(4): 451 (1995), emend. L. Fan \& X.Y. Yan

\section{Description}

Basidiomata 1.5-2 $\times 0.5-1.5 \mathrm{~cm}$, hypogeous, subglobose, yellow brown to brown when fresh, rust brown to deep brown when dry; rhizomorphs few, brown; sweet odor, like fruits flavor. Gleba firm, black, with sterile white veins scattered throughout. Peridium two-layered, epicutis $60-100 \mu \mathrm{m}$ thick, composed of interwoven hyphae, yellow brown, 5-7.5 $\mu \mathrm{m}$ in diam, clamp connections visible; subcutis 100-200 $\mu \mathrm{m}$ thick, compactly interwoven hyphae, with some inflated cells, ellipsoidal, irregular, up to 7.5-15 $\mu \mathrm{m}$ wide, light yellowish to yellowish brown walls toward surface. Trama plates of interwoven hyphae, hyaline to pale yellow, 2.5-4 $\mu \mathrm{m}$ in diam. Basidia not observed. Basidiospores obovate, appearing smooth under LM, irregularly tiny verrucose under SEM, 8.7-10.6 × 6.6$8.0 \mu \mathrm{m}(\mathrm{avX}=9.8 \pm 0.5 \times 7.0 \pm 0.4, \mathrm{n}=50), \mathrm{Q}=1.1-1.5(\mathrm{avX}=1.4 \pm 01, \mathrm{n}=50)$, yellowish brown to brown, walls $1 \mu \mathrm{m}$ thick.

\section{Habit, habitat and distribution}

Summer (July), in soil under Quercus sp. Warm temperate zone of North China.

Notes: Melanogaster subglobisporus is diagnosed by its yellow brown to brown basidiomata and obovate basiodiospores decorated with irregularly tiny verrucose under SEM. Melanogaster subglobisporus has obovoid or subglobose and smooth basidiospores in original descriptions (Wang et al. 1995). However, afterchecking the holotype and two specimens of M. subglobisporus (collected from type location) cited in Flora Fungorum Sinicorum (Vol. 7) (Liu et al., 1998), we confirmed its spores were ornamented with irregularly tiny verrucose under SEM. Phylogenetically, the sequence of holotype (HMAS83329 ex MHSU2001) clustered in the independent clade M and showed less than $91.49 \%$ ITS similarity with other species. Therefore we recognized the phylogenetic position of $M$. subglobisporus and emended the description with illustration. Phylogenetically and Morphyologically, M. spinisporus is related to M. subglobisporus with similar spore shape and size. However, M. spinisporus differs from M. subglobisporus by its light brown with some red brown or brick red basidiomata and basidiospore ornamented by short strip, even connected into small pieces, irregularly verrucose under SEM.

Material examined: CHINA. SHANXI PROV.: Jincheng City, Yangcheng County, Yangzhuang river, Alt. 580-600 m, 16 July 1990, Y. Ma, M.-c. Chang 504 (HMAS83329 ex MHSU2001, Holotype); ibid., Y. Ma, M.-c. Chang 243 (HMAS81919 ex MHSU2107, epitype, designated here); ibid., Alt. 600-620 m, under Quercus sp., 13 July 1990, M.-c. Chang 500 (HMAS81921 ex MHSU2110).

Melanogaster tomentellus L. Fan \& X.Y. Yan sp. nov. MycoBank MB Fig. 4, s-w

Etymology: tomentellus, referring to the tomentose surface of the basidiomata.

Type: CHINA. YUNNAN PROV.: Kunming City, Xishan District, Haikou Town, in soil under Pinus sp., Alt. 1900 m, 8 January 2016, J.-z. Cao 1707 (BJTC FAN539).

Diagnosis: Melanogaster tomentellus could be easily diagnosed by its minutely green tomentose surface of basidiomata, small and elongate-fusiform spores.

\section{Description}

Basidiomata 1.1-2.2 ×1.9-2.5 cm, hypogeous, globose to subglobose, brown to deep brown, surface minutely green tomentose, without distinct basal zone, few brown rhizomorphs; odor strong turpentine flavor. Gleba black, solid, gelatinous, with sterile white veins scattered throughout. Peridium single-layered, 250-350 $\mu \mathrm{m}$ thick, textura globosa to textura prismatica structure (pseudoparenchymatous), made of short, subglobose, ellipsoidal or irregular round hyphae, 5-30 $\mu \mathrm{m}$, thin-walled, light yellowish to yellow brown walls toward outside surface. Cystidia up to $15-40 \mu \mathrm{m}$ long and 5-7.5 $\mu \mathrm{m}$ broad at base arising from some of the outermost cells of the peridium, clamp connections visible, thick-walled at apical tips. Trama composed of gelatinized hyphae. Basidia not observed. Basidiospores elongate fusiform, $8-11.4 \times 3.8-5.6 \mu \mathrm{m}(\mathrm{avX}=9.4 \pm 0.8 \times 4.5 \pm 0.4, \mathrm{n}=50), \mathrm{Q}=1.7-2.7(\mathrm{avX}=2.1 \pm 0.2, \mathrm{n}=50)$, brown, walls $0.5 \mu \mathrm{m}$ thick, smooth, the base broadly truncate-cupped, with very short remnants of sterigmata.

\section{Habit, habitat and distribution}

Winter (January), in soil under Pinus sp., plateau subtropical evergreen forests of Southern China.

\section{Notes}

Phylogenetically, the sequence of holotype (BJTC FAN539) clustered in the independent clade $L$ with strong support (BS $=97 / \mathrm{PP}=1.00)$ and showed less than 95.33\% ITS similarity with other species. Therefore, we proposed $M$. tomentellus as a new species from China. M. obovatus, M. quercus and M. shanxiensis 
are related to $M$. tomentellus phylogenetically. However, $M$. obovatus and $M$. quercus differ from $M$. tomentellus in their light brick red or orange brown surface and yellowish or yellow brown basidiospores. M. shanxiensis differs from M. tomentellus in its white to pale yellow surface, yellow brown and big basidiospores $(10.5-14.5 \times 5.0-6.5 \mu \mathrm{m})$.

\section{Key to species of Melanogaster from China}

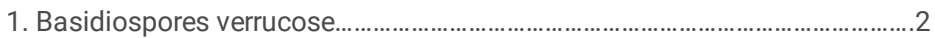

1. Basidiospores smooth ...............................................................................

2. Basidiospores appearing smooth or decorated with sparse spine under light microscope (LM), but short strip, even connected into small pieces, irregularly verrucose under scanning electron micro-scope (SEM), 7.4-12.0 × 5.2-9.2 $\mu \mathrm{m}$. M. spinisporus

2. Basidiospores appearing smooth under LM, irregularly tiny verrucose under SEM, 8.7-10.6 × 6.6-8.0 $\mu \mathrm{m}$. $M$. subglobisporus

3. Basidiospores light yellow to yellow brown .4

3. Basidiospores brown to deep brown or reddish brown .7

4. Basidiospores ovoid to ellipsoid, small, $5-7 \mu \mathrm{m}$ long ... ovoidisporus

4. Basidiospores broadly citriform or obovatus to fusiform, large, 9.5-16 $\mu \mathrm{m}$ long, . .5

5. Basidiospores elongate-obovatus to narrowly oblong, $10.5-14.5 \times 5.0-6.5 \mu \mathrm{m}$............. shanxiensis

5. Basidiospores broadly citriform or obovatus, $9.6-13.3 \times 4.8-9.8 \mu \mathrm{m}$ M. natsii

5. Basidiospores elongate-fusiform, $10-15 \times 4.6-7.7 \mu \mathrm{m}$. ...6

6. Gleba yellow green to yellow brown, basidiospores elongate-fusiform with rounded top, or obovate obovatus

6. Gleba black, basidiospores elongate-fusiform with apiculate apex M. quercus

7. Basidiospores reddish brown M. panzhihuaensis

7. Basidiospores yellow brown to deep brown .8 
8. Basidiospores obovoid

9. Basidiospores fusiform, apex bluntly apiculate, $10.0-15.9 \times 4.8-6.3 \mu \mathrm{m}$ M. fusisporus

9. Basidiospores elongate fusiform, apex apiculate, $8-11.4 \times 3.8-5.6 \mu \mathrm{m}$. M. tomentellus

10. Gleba yellowish to brown, basidiospores obovoid, sometimes narrowly oblong or ellipsoid, $6.5-8 \times 3.8-4.7$ $\mu \mathrm{m}$ M. obovatisporus

\section{Discussion}

\section{The circumscription and diversity of Melanogaster}

Totally 21 phylotypes were defined based on ITS phylogeny (Fig. 1), of which 9 phylotypes were recognized as known species, including $M$. intermedius, $M$. ambiguus, $M$. euryspermus, $M$. spinisporus, $M$. shanxiensis, $M$. subglobisporus, M. rivularis, M. luteus and M. broomeanus, 5 phylotypes were described as 4 new species and 1 new combination based on the Chinese collections in this present study. The remaining 7 phylotypes were most likely new species of the genus Melanogaster. Moreover, it should be mentioned that there were still 15 species not to be included in the present molecular analysis among the about 25 species accepted in Melanogaster before this study, including Melanogaster carolinensis (Bosc ex Spreng.) De Toni, Melanogaster cauvinianus (Corda) Mont. ex Berl., De Toni \& E. Fisch., Melanogaster durissimus Cooke, Melanogaster eisenii Harkn., Melanogaster macrocarpus Zeller, Melanogaster minisporus Cázares, G. Guevara, J. García \& Trappe, Melanogaster natsii, Melanogaster ovoidisporus, Melanogaster parksii Zeller \& C.W. Dodge, Melanogaster trappei I.P.S. Thind \& B.M. Sharma, Melanogaster tuberiformis Corda, Melanogaster umbriniglebus Trappe \& Guzmán, Melanogaster utriculatus, Melanogaster variegates and Melanogaster vittadinii Soehner \& Knapp. These putative novel species and old species without DNA data required more mycologists to pay attention to them in the future. Morphologically, the spore shape and size of a species is basically regular and stable, which is usually used in the species delimitation of Melanogaster, but all in all, the combination of spore characteristics, peridium structure, color of basidiomata and gleba, can perfectly help us distinguish species. For example, M. obovatus and $M$. quercus have similar spore shape and size, the gelba, however, is yellow green to yellow brown in $M$. obovatus, but black in M. quercus, by which the two species are completely differentiated from each other.

DNA analyses revealed that a threshold of $98 \%$ identity in ITS sequence could be also used as the delimitation of Melangaster species. Most of species delimitated in this study share less than $98 \%$ ITS similarity from each other. Furthermore, combined our result with previous published data, we basically proposed the main diagnostic characteristics for the genus Melanogaster. Basidiomata without distinct basal zone; Peridium single or two-layered, composed of interwoven hyphae or textura globosa to texturaprismatica structure (pseudoparenchymatous), clamp connections visible usually; Gleba gelatinous, with sterile veins scattered throughout, basidia clavate, 2-8-spored, which were no regularly arranged in a definite palisade, but irregularly distributed through broad hyphal zone lining the cavities; Basidiospores ellipsoid, subglobose, fusiform or lemon shaped, most deeply colored, some light colored, most smooth, a few decorated with verrucose or utricle.

According to the literatures from Europe (Berkeley, 1844; Moreno et al. 1986; Ainsworth, 2005; Lacheva, 2015), North America (Harkness, 1899), Asia (Liu et al, 1989; Wang et al. 1995, 2005), and Oceania (Cunningham et al, 1934), the genus Melanogaster form ectomycorrhizae with a wide range of host plant, including: Acersp., Alnus sp., A. alnobetula (Ehrh.) K.Koch, A. cordata (Loisel.) Duby, Corylus avellana L., Fagus sp., F. sylvatica L., Lithocarpus densiflorus (Hook. \& Arn.) Rehder, Lonicera japonica, Pinus sylvestris L., Populus nigra L., Pseudotsuga menziesii (Mirb.) Franco, Quercus sp., Q. liaotungensis, Spiraea pubescens, Tsuga sp. In China, according to our present research, the host included Lonicera japonica, Ostryopsis davidiana, Pinus bungeana, Pinus tabuliformis, Quercus acutissima, Quercus mongolica, Quercus liaotungensis, Spiraea pubescens. In conclusion, the Melanogaster species mainly establish symbiosis with plants of Fagaceae, Pinaceae, and Betulaceae, which may be the reason why the genus Melanogaster is widely distributed.

Additionally, our phylogenetic analyses revealed that some samples labled as "Alpova trappei" were grouped into the Melanogaster clade (Fig. 1, 2), indicating they probably represented the species of Melanogaster rather than that of Alpova. However,whether these samples were misidentification or the species "Alpova trappei" should be transfer to Melanogasterneed further research.

\section{Melanogaster in China}


Up to now, there are ten species and varieties to be described from China based on morphological data alone according to our data. In the present study the collections of Melanogaster from China, including the old specimens deposited in HMAS and KUN-HKAS, and the ones recently collected by us, were researched using morphological and molecular phylogenetic methods. Consequently, the occurrence of four known species in China was confirmed, including M. broomeanus, M. shanxiensis, M. spinisporus, M. subglobisporus. The variety M. ovoidisporus var. angustatisporus was treated as synonym of $M$. broomeanus, while $M$. fusisporus var. obvatus was raised to species level as $M$. obvatus. DNA sequences of the other four species, $M$. fusisporus, $M$. obovatisporus, M. ovoidisporus and M. natsii, were not successfully sequenced in this study because the type specimens and reliable specimens cited in Flora Fungorum Sinicorum (Vol. 7) (Liu et al., 1998) are old or poorly preserved, but they have distinct morphological features according to our reexaminations for their type specimens and reliable specimens. We therefore confirmed their occurrence in China. Moreover, four new species were proposed from China based on the newly collected specimens, including M. minobovatus, M. panzhihuaensis, M. quercus and M. tomentellus.

Totally, the occurrence of 13 Melanogaster species in China were confirmed in present study. In addition, there are still potential Melanogaster species that have not been discovered in China, such as the sequence of ECM (HM105535), which chould represent a potential new taxon (Phylotype R: labeled as M.sp.6, Fig. 1) from China.

\section{Conclusions}

ITS phylogenetic analysis for the genus Melanogaster showed 21 phylogenetic species. Thirteen species were found from China including 8 known species, 4 species and one new combination. Their descriptions, illustrations and key were provided. This work is the first detailed morphological and phylogenetic analysis for the Chinese Melanogaster species, which would contribute to future research on Melanogaster.

\section{Abbreviations}

LM: light microscope; SEM: scanning electron micro-scope; ML: maximum likelihood BS:maximum PP: Bayesian posterior probabilities; HMAS: Herbarium Mycologicum Academiae Sinicae, Institute of Microbiology, Chinese Academy of Sciences; KUN: Herbarium, Kunming Institute of Botany, Chinese Academy of Sciences; ITS: Ribosomal DNA internal transcribed spacer region; nrLSU: nuclear ribosomal large subunit.

\section{Declarations}

\section{Ethics approval and consent to participate}

Not applicable

\section{Adherence to national and international regulations}

Not applicable.

\section{Consent for publication}

Not applicable.

\section{Availability of data and materials}

Alignments and tree files generated during the current study are available in the TreeBASE (accession https://www.treebase.org/treebase-web/home.html; study ??). All sequence data are available in NCBI Genbank following the accession numbers in the manuscript.

\section{Competing interests}

The authors declare that they have no competing interests.

\section{Funding}

The study was supported by the National Science Foundation of China (No. 31270058) and the Beijing Natural Science Foundation (No. 5122003).

\section{Authors' contributions}

XY wrote the manuscript, made a substantial contribution to the conception of the study, interpreted the sequence data and performed the phylogenetic analysis and microscopy. LF contributed to microscopic examination of fungal specimens, advised on the interpretation of the taxonomy, and was a major contributor in writing the manuscript. YX and TL assisted in the analyses of the data and advised on the interpretation of the taxonomy. TZ and JL contributed to the collection of fungal specimens and made a substantial contribution to the conception of the study. All the authors read and approved the final manuscript. 


\section{Acknowledgments}

The authors thank the curators of the herbaria of HMAS and KUN for providing specimens and permission of the DNA extraction from them. The authors are grateful to Dr. J.Z. Cao and Mr. JS Xu for collecting specimens and providing valuable suggestions.

\section{References}

1. Ainsworth M (2005) Melanogaster intermedius a Slime Truffle rediscovered in England after 159 years. Field Mycology Volume 6(4). doi:10.1016/s14681641(10)60331-3

2. Alfaro ME, Zoller S, Lutzoni F (2003) Bayes or bootstrap? A simulation study comparing the performance of Bayesian Markov chain Monte Carlo sampling and bootstrapping in assessing phylogenetic confidence. Molecular Biology and Evolution 20:255-266. doi: 10.1093/molbev/msg028

3. Altschul S, Madden T, Schaffer A et al. (1997) Gapped BLAST and PSI-BLAST: a new generation of protein database search programs. Nucleic Acids Research 25:3389-3402 doi:10.1093/nar/25.17.3389

4. Binder M, Hibbett DS (2006) Molecular Systematics and Biological Diversification of Boletales. Mycologia 98(6):971-981. doi:10.1080/15572536.2006.11832626

5. Bonito GM, Gryganskyi AP, Trappe JM, Vilgalys R (2010) A global meta-analysis of Tuber ITS rDNA sequences: species diversity, host associations and long-distance dispersal. Molecular Ecology 19(22):4994-5008. doi: 10.1111/j.1365-294X.2010.04855.X

6. Brock PM, Doring H, Bidartondo MI (2009) How to know unknown fungi: the role of a herbarium. New Phytol. 181(3),719-724. doi:10.1111/j.14698137.2008.02703.x

7. Castresana J (2000) Selection of conserved blocks from multiple alignments and their use in phylogenetic analysis. Molecular Biology and Evolution 17:540-552. doi:10.1093/oxfordjournals.molbev.a026334

8. Corda AKJ (1831) Die Pilze Deutschlands. In: Sturm J. (ed.), Deutschlands Flora 3rd ed 3(12):1-36.

9. Dring DM (1971) Techniques for microscopic preparation. Methods in microbiology. Vol. 4. New York: Academic Press. p. 95-111.

10. Gardes M, Bruns TD (1993) ITS primers with enhanced specificity for basidiomycetes application to the identification of mycorrhizae and rusts. Molecular Ecology 2: 113-118. doi:10.1111/j.1365-294X.1993.tb00005.x

11. Hillis DM, Bull JJ (1993) An empiricaltest of bootstrapping as a method for assessing confidence in phylogenetic analysis. Systematic Biology 42:182192. doi: $10.2307 / 2992540$

12. Keissler K, Lohwag H (1937) Fungi in Handel-Mazzeti Symbolae Sinicae. 2: 37-66.

13. Lacheva M (2015) New records of Melanogaster species (Fungi, Boletales) in Bulgaria. Journal of Biodiversity and Environmental Sciences 6:494-500.

14. Liu B, Tao K, Cang MC (1989) Two new species of Melanogasterfrom China. Acta Mycologia Sinica 8(3):210-213.

15. Moreau PA, Rochet J, Richard F, Chassagne F, Gardes M (2013) Taxonomy of Alnus-Associated Hypogeous Species of Alpova and Melanogaster (Basidiomycota, Paxillaceae) in Europe. Cryptogamie Mycologie 32(1): 33-62. doi:10.7872/crym.v32.iss1.2012.033

16. Moreau PA, Welti S, Perić B, Jargeat P, Manzi S, Vizzini A (2012) Alpova komoviana (Boletales, Paxillaceae), a new sequestrate fungus from Montenegro, with a revised phylogeny of the genus in Europe. Mycological Progress 12:109-119. doi:10.1007/s11557-012-0818-x

17. Nilsson RH, Kristiansson E, Ryberg M, Larsson KH (2005) Approaching the taxonomic affiliation of unidentified sequences in public databases - an example from the mycorrhizal fungi. BMC Bioinformatics 6:178. doi:10.1186/1471-2105-6-178

18. Nylander JAA (2004) Mr Modeltest 2.2. Computer software distributed by the University of Uppsala. Uppsala, Sweden: Evolutionary Biology Centre, University of Uppsala.

19. Orihara T, Smith ME, Shimomura N, Iwase K, Maekawa N (2012) Diversity and systematics of the sequestrate genus Octaviania in Japan: two new subgenera and eleven new species. Persoonia, 28(6):85-112. doi:10.3767/003158512X650121

20. Page RD (2001) TreeView. Glasgow University, Glasgow.

21. Rambaut A (2000) Estimating the rate of molecular evolution: incorporating non-contemporaneous sequences into maximum likelihood phylogenies. Bioinformatics 16:395-399. doi:10.1093/bioinformatics/16.4.395

22. Ronquist F, Huelsenbeck JP (2003) MrBayes3: Bayesian phylogenetic inference under mixed models. Bioinformatics 19:1572-1574. doi:10.1093/bioinformatics/btg180

23. Ryberg M, Kristiansson E, Sjokvist E, Nilsson RH (2009) An outlook on the fungal internal transcribed spacer sequences in GenBank and the introduction of a web-based tool for the exploration of fungal diversity. New Phytologist 181:471-477. doi:10.1111/j.1469-8137.2008.02667.x

24. Stamatakis A (2006) RAxML-VI-HPC:maximum likelihood based phylogenetic analyses with thousands of taxa and mixed models. Bioinformatics 22:2688-2690. doi:10.1093/bioinformatics/bt/446

25. Stamatakis A (2014) RAxMLversion8: a tool for phylogenetic analysis and post-analysis of large phylogenies. Bioinformatics 30:1312-1313. doi:10.1093/bioinformatics/btu033

26. Stamatakis A, Ludwig T, Meier H (2005) RAxML-III: a fast program for maximum likelihood-based inference of large phylogenetic trees. Bioinformatics 21:456-463. doi:10.1093/bioinformatics/bti191

27. Teng SC (1963) Fungi of China. Beijing, China: Science Press, p. 660.

28. TÜRKOĞLU A, CASTELLANO MA (2013) New records of truffle fungi (Basidiomycetes) from Turkey. Turkish Journal of Botany 37 : $970-976$. doi:10.3906/bot-1212-54

Page 19/23 
29. Vilgalys R, Hester M (1990) Rapid genetic identification and mapping of enzymatically amplified ribosomal DNA from several species of Cryptococcus species. Journal of Bacteriology 172:4238-4246. doi:10.1128/jb.172.8.4238-4246.1990

30. Wang Y, Chang MC, Tao K, Liu B (1995) New species and new varietiesin the genus Melanogaster from China. Journal of Shanxi University (Natural Science Edition) 18(4):449-453. doi:CNKI:SUN:SXDR.0.1995-04-020

31. White TJ, Bruns T, Lee S, Taylor JW (1990) Amplification and direct sequencing of fungal ribosomal RNA genes for phylogenetics. In: Innis MA, Gelf and DH, Sninsky JJ, White TJ, eds. PCR protocols: a guide to the methods and applications. New York: Academic Press. p. 315-322. doi:10.0000/PMID1793 32. Yuan MS, Sun PQ (1996) Sichuan Mushroom. Sichuan, China: Sichuan Science and Technology Press.

\section{Figures}

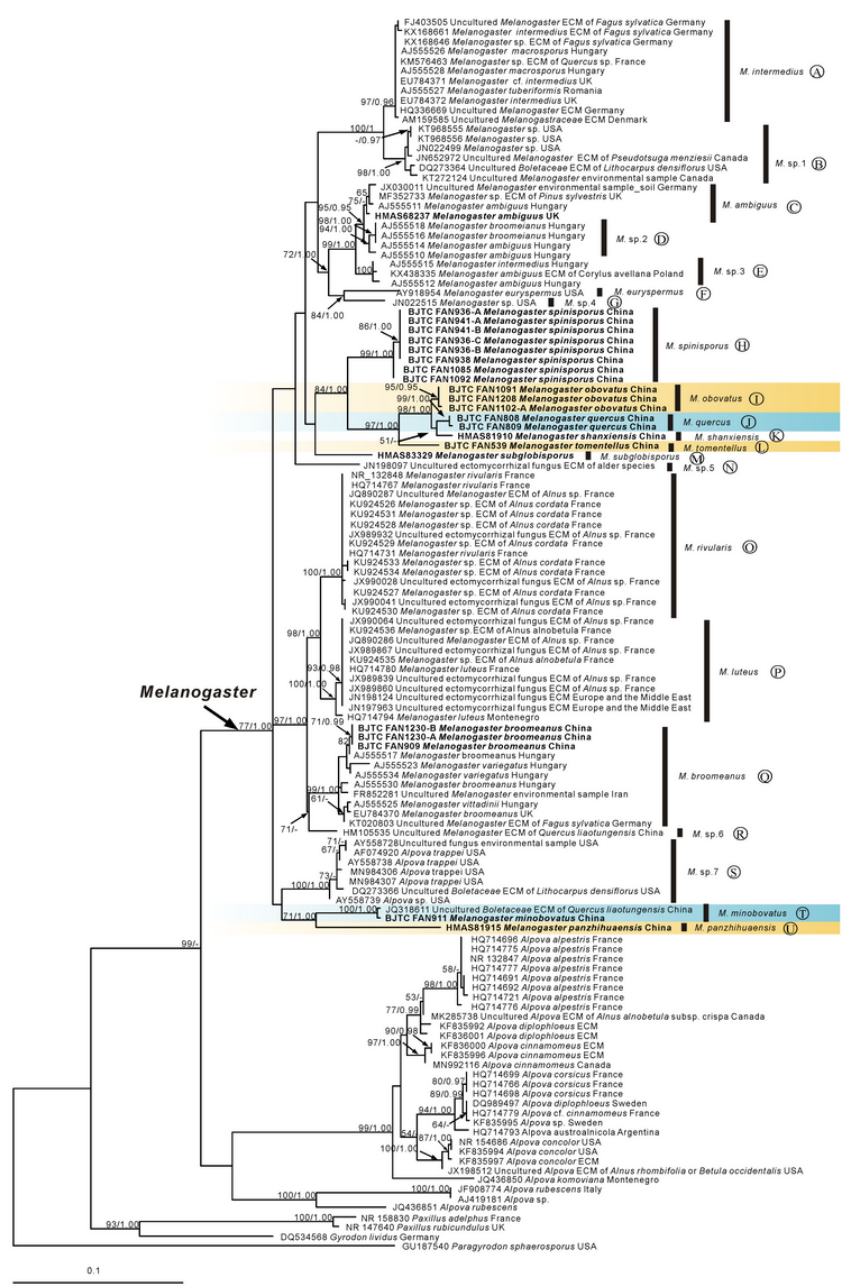

Figure 1

Phylogeny derived from maximum likelihood (ML) analysis of the nrDNA-ITS sequences from the Melanogaster and Alpova species. Values next to nodes reflect: left maximum likelihood bootstrap support values (BS) and right Bayesian posterior probabilities (PP). Names of novel species and samples with newly generated sequences in bold. 


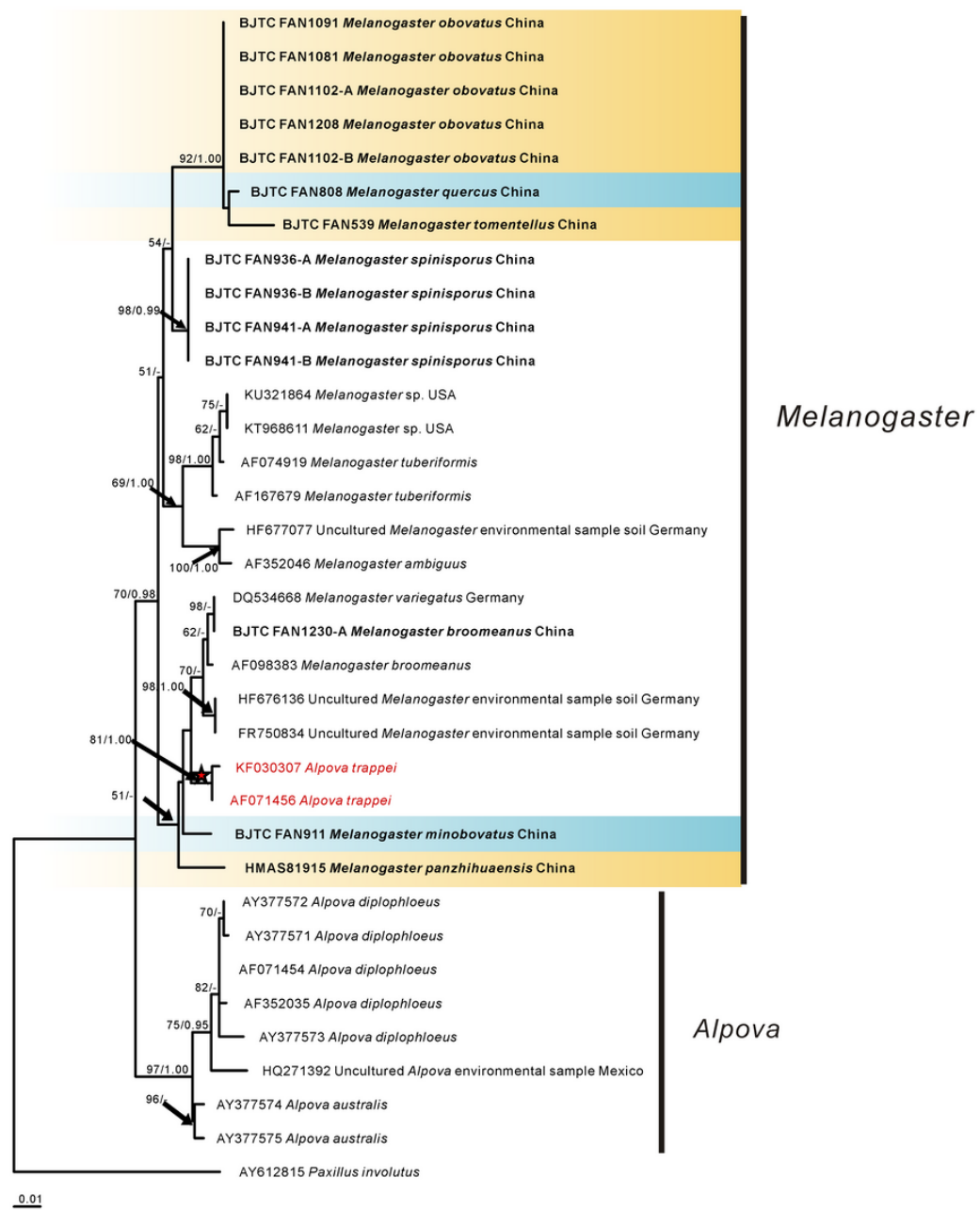

Figure 2

Phylogeny derived from maximum likelihood (ML) analysis of the nrLSU sequences from the Melanogaster and Alpova species. Values next to nodes reflect: left maximum likelihood bootstrap support values (BS) and right Bayesian posterior probabilities (PP). Names of novel species and samples with newly generated sequences in bold. 


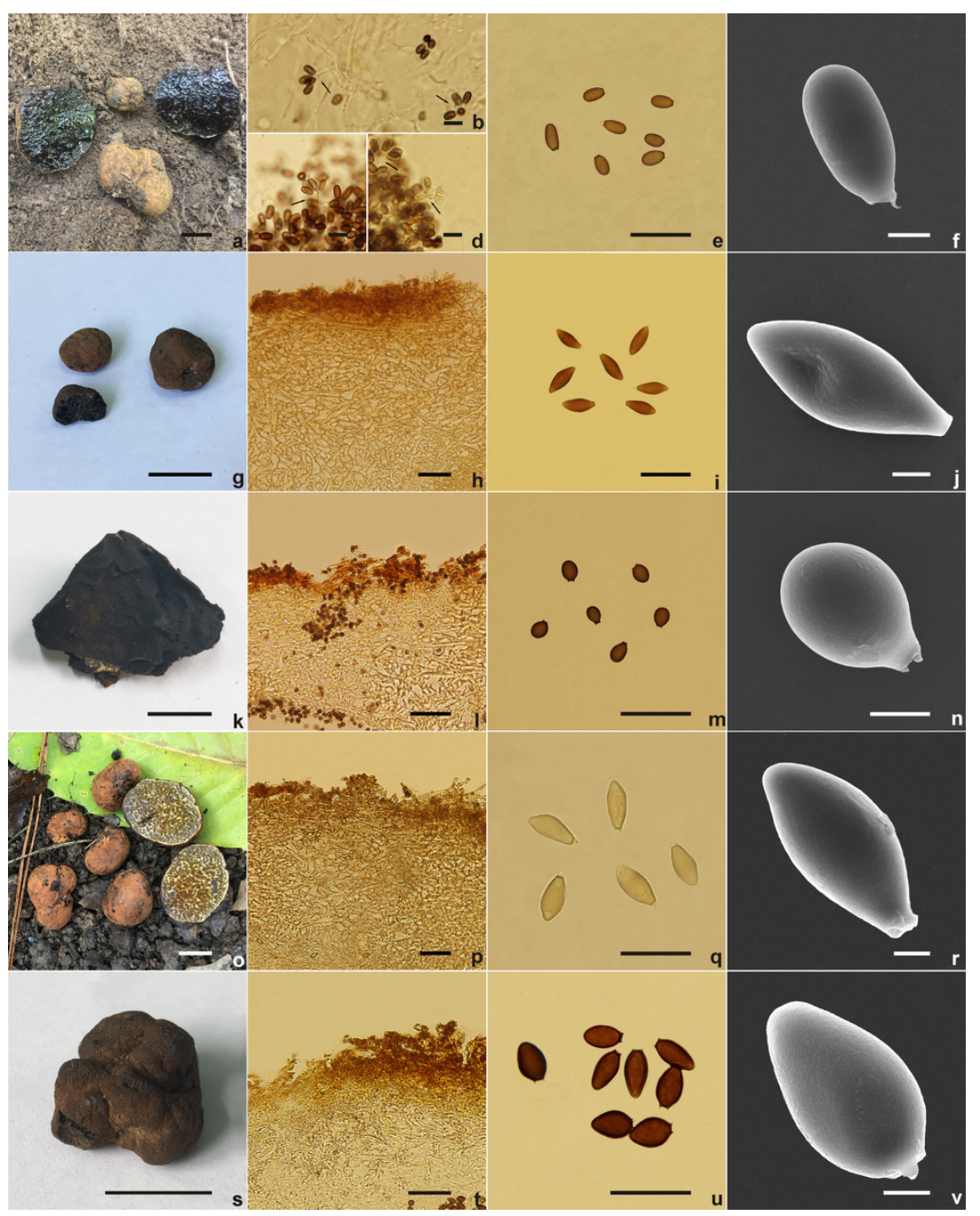

Figure 3

Photographs of Melanogaster species. Melanogaster broomeanus. a Basidiomata (BJTC FAN1230). b-d. LM of basidia and basidiospores (BJTC FAN909). e. LM of basidiospores (BJTC FAN1230). f. SEM of ascospore (BJTC FAN1230). Melanogaster fusisporus (HMAS83274). g. Basidiomata. h. LM of Peridium. i. LM of basidiospores. j. SEM of ascospore. Melanogaster minobovatus (BJTC FAN911, holotype). k. Basidioma. I. LM of Peridium. m. LM of basidiospores. $n$. SEM of ascospore. Melanogaster obovatus (BJTC FAN1091, epitype). o. Basidiomata. p. LM of Peridium. q. LM of basidiospores. r. SEM of ascospore. Melanogaster panzhihuaensis (HMAS81915, holotype). s. Basidioma. t. LM of Peridium. u. LM of basidiospores. v. SEM of ascospore. Scale bars: a, g, k, o, $\mathrm{s}=1 \mathrm{~cm} ; \mathrm{b}, \mathrm{c}, \mathrm{d}=10 \mu \mathrm{m} ; \mathrm{e}, \mathrm{i}, \mathrm{m}, \mathrm{q}, \mathrm{u}=20 \mu \mathrm{m} ; \mathrm{f}, \mathrm{j}, \mathrm{n}, \mathrm{r}, \mathrm{v}=2 \mu \mathrm{m} ; \mathrm{h}, \mathrm{l}, \mathrm{p}, \mathrm{t}=50 \mu \mathrm{m}$. 


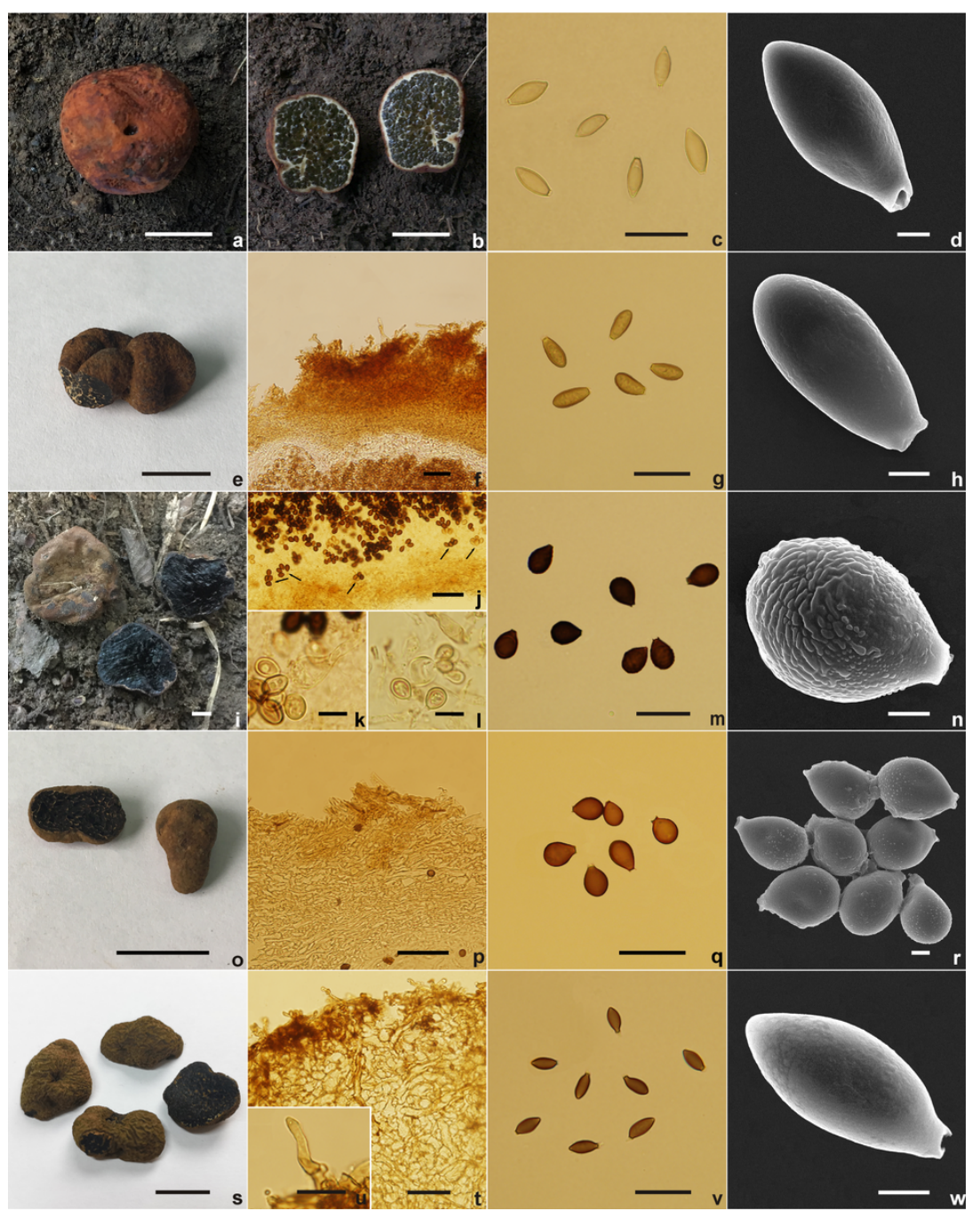

\section{Figure 4}

Photographs of Melanogaster species. Melanogaster quercus (BJTC FAN809, holotype). a-b. Basidiomata. c. LM of basidiospores. d. SEM of ascospore. Melanogaster shanxiensis (HMAS81910, holotype). e. Basidioma. f. LM of Peridium. g. LM of basidiospores. h. SEM of ascospore. Melanogaster spinisporus (BJTC FAN941-A, epitype). i. Basidiomata. j-I. LM of basidia and basidiospores. $\mathrm{m}$. LM of basidiospores. $\mathrm{n}$. SEM of ascospore. Melanogaster subglobisporus (HMAS81919, epitype). o. Basidiomata. p. LM of Peridium. q. LM of basidiospores. r. SEM of ascospores. Melanogaster tomentellus (BJTC FAN539, holotype). s. Basidiomata. t. LM of Peridium. u. LM of cystidia v. LM of basidiospores. w. SEM of ascospores. Scale bars: a, b, e, i, o, s=1cm; c, g, m, q, v=20 $\mu$; ; $\mathrm{h}, \mathrm{n}$, $w=2 \mu \mathrm{m} ; \mathrm{f}, \mathrm{j}, \mathrm{p}, \mathrm{t}=50 \mu \mathrm{m} ; \mathrm{k}, \mathrm{l}, \mathrm{u}=50 \mu \mathrm{m} ; \mathrm{r}=5 \mu \mathrm{m}$. 